\title{
PENDEKATAN BARU MAQASID AL-SHARIAH DALAM PENGAJIAN SYARIAH DI MALAYSIA: SATU ANALISIS ${ }^{1}$
}

\author{
Oleh: \\ Rahimin Affandi Abdul Rahim \\ Paizah Ismail \\ Idris Awang
}

\begin{abstract}
The article attempts to forward a holistic approach of Maqasid of al-shariah in Shariah Studies in Malaysia. The proposal is based on the belief that the concept of Maqasid al-Shariah as well as its application has its own significance in the programming of Shariah Studies in Malaysia. The discussion begins by introducing the essentiality of Maqasid al-Shariah, the needs in the process of globalization and their relevance in Maqasid alShariah, and an analysis of the proposed approach as implemented in the Shariah Studies at the Academy of Islamic Studies, University of Malaya.
\end{abstract}

\section{PENGENALAN}

Dewasa ini, terdapat semacam kesedaran di kalangan penganut Islam di Malaysia tentang sifat dinamisme dan kemampuan hukum Islam menangani pelbagai isu moden yang timbul di dalam masyarakat. ${ }^{2}$ Sebagai langkah

Artikel ini merupakan olahan baru daripada kertas kerja yang dibentangkan dalam International Conference: Islamic Jurisprudence and the Challenges of The 21 ${ }^{\text {st }}$ Century, anjuran UIAM, pada 8 Ogos 2006.

2 Hal ini boleh didapati dalam Rahimin Affandi Abdul Rahim (2005), "Citra Islam Dalam Pembentukan Manusia Melayu Moden Di Malaysia: Suatu Analisa," dalam Jurnal Pengajian Melayu, V. 15, hlm. 19-51. 
Jurnal Fiqh: No. 3 (2006)

proaktif, berhadapan dengan perkembangan positif ini, seseorang fuqaha sama ada yang terlibat di dalam institusi pendidikan ataupun institusi penguatkuasaan undangundang tidak boleh leka dan mengambil sikap bersahaja, sebaliknya perlu memikirkan langkah terbaik untuk memperkasakan lagi hukum Islam semasa, ${ }^{3}$ khususnya yang membabitkan bidang pengajian syariah. ${ }^{4} \mathrm{Hal}$ ini dipertegaskan berasaskan kepada tiga peranan penting yang boleh dimainkan oleh institusi pendidikan Islam bagi menjamin pembangunan sesebuah negara;

1. melahirkan insan (warganegara) yang sempurna dan seimbang, dari segi jasad, ruh dan akal bagi memenuhi tujuan pengabdiaan kepada Allah. ${ }^{5}$ Seperti ditegaskan oleh S.M. Naguib matlamat utama institusi pendidikan tinggi Islam adalah bagi melahirkan manusia yang bersifat universal dipandang dari segi ilmu, kesedaran diri dan praktikal akhlaknya. ${ }^{6}$

2. bagi melahirkan tenaga kerja dan intelektual ummah yang mampu berkhidmat kepada masyarakat secara berkesan dan berhemah mengikut bidang kemahiran yang tertentu. Bagi Ayumardi Azra, dalam soal ini, dua elemen utama boleh dikesan; tenaga mahir untuk sesuatu sektor pekerjaan dan nisbah professioanalisme yang lebih berteraskan kepada

3 Mahmood Zuhdi Abd. Majid (1997), Pengantar Undang-undang Islam di Malaysia, Kuala Lumpur: Penerbit Universiti Malaya, hlm 34-40.

4 Lihat sebagai contoh Ahmad Hidayat Buang (2004), "Penyediaan dan Pengeluaran Fatwa," dalam Ahmad Hidayat Buang (ed.), Fatwa di Malaysia, Kuala Lumpur: Jabatan Syariah dan Undang-Undang, APIUM, hlm 97-116.

5 Lihat sebagai contohnya Rahimin Affandi Abdul Rahim, "Islam dan Perkembangan Emosi Melayu Selepas Merdeka: Satu Analisis," kertas kerja Seminar Antarabangsa Pengajian Melayu - Emosi Melayu, anjuran Akademi Pengajian Melayu Universiti Malaya, pada $12 \mathrm{hb}$ Julai 2003

6 S.M. Naguib al-Attas (1978), Islam and Secularism, Kuala Lumpur: ABIM, hlm 147-152. 
Pendekatan Baru Maqasid al-Shariah Dalam Pengajian Syariah di Malaysia

prinsip keislaman yang tinggi. Sifat intelektualprofessional ini dikatakan sebagai faktur utama yang boleh melahirkan tamadun umat Islam yang bermutu dan berwawasan Tauhid. ${ }^{7}$

3. bagi melahirkan golongan ilmuan dan sarjana yang boleh membangun dan mengembangkan sesuatu disiplin keilmuan Islam moden. Masa depan umat Islam boleh dikatakan antara lainnya bergantung sepenuhnya kepada golongan ilmuan ini. ${ }^{8}$

Merujuk khusus kepada perkara ke (3), artikel ini akan cuba menjawab dua persoalan utama yang mempunyai kaitan dengan konsep Maqasid al-Shariah;

1. Bagaimanakah usaha berperancangan rapi membabitkan kurikulum dan pedagogi pengajian syariah yang dijalankan oleh APIUM, bagi melahirkan sejumlah besar kalangan sarjana (fuqaha) Islam yang kompeten - dilihat dari sudut ianya tidak melupakan warisan fuqaha silam dan meraikan perkembangan keilmuan semasa, termasuklah juga fenomena globalisasi (khususnya membabitkan institusi pendidikan tinggi) yang sedang melanda dunia.

2. Memberi respon terhadap gagasan yang cuba menjadikan konsep Maqasid al-Shariah ataupun maslahah ini secara asas utama dalam menjalankan program pembaharuan pemikiran hukum Islam. Mengikut pandangan Hasbi al-Siddiqei, upaya memecahkan masalah hukum Islam tidak cukup hanya bertumpu kepada metode Qiyas semata-mata seperti mana dipakai secara meluas dalam mazhab Shafi'i. Tindakan ini bakal menyebabkan hukum Islam tidak mampu memenuhi tuntutan perubahan

Ayumardi Azra (1998), Esei-esei Intelektual Muslim dan Pendidikan Islam, Jakarta: Logos, hlm 4-6.

8 Saedah Siraj (2001), Perkembangan Kurikulum: Teori dan Amalan, Sungai Buloh, hlm 15-19. 
Jurnal Fiqh: No. 3 (2006)

zaman, bahkan seandainya metode Qiyas ini dipaksakan pemakaiannya dalam konteks zaman moden, ianya bakal menyebabkan banyak kemaslahatan manusia akan terabai. Atas dasar inilah, beliau menekankan peri pentingnya penetapan kaedah penetapan hukum yang berbasiskan konsep Maqasid al-Shariah. ${ }^{9}$

\section{TUNTUTAN GLOBALISASI DALAM PENDIDIKAN DAN KAITANNYA DENGAN PRINSIP MAQASID AL- SHARIAH}

Secara kasarnya, para pengubal dan pengamal institusi pendidikan perundangan Islam di Malaysia telah mencurahkan begitu banyak tenaga bagi menjalankan usaha reformasi (tajdid), sehingga usaha ini telah mendapat pengiktirafan di peringkat antarabangsa. ${ }^{10}$ Selaras dengan kemerdekaan yang telah dicapai oleh Tanah Melayu, beberapa orang sarjana Melayu post kemerdekaan dengan pertimbangan nasionalisme telah melakukan review ${ }^{11}$ dan pembetulan ${ }^{12}$ terhadap warisan

9 Mahsun Fuad (2005), Hukum Islam Indonesia: Dari Nalar Partisipatoris Hingga Emansipatoris, Yogyakarta: LKIS, hlm 201-202.

10 Osman Bakar (2004), "Globalisasi dan Tamadun Islam: Satu Wacana Awal," dalam Mohamed Anwar Omar Din (ed.), Dinamika Bangsa Melayu: Menongkah Arus Globalisasi, Bangi: Penerbit UKM, hlm 203207.

11 Sebagai contohnya, proses penilaian semula (reviewing) telah dilakukan kepada disiplin sejarah (Lihat Zainal Abidin Abdul Wahid (1992), Sejarah Malaysia: Pentafsiran dan Penulisan, Bangi), antropologi dan sosiologi (Lihat Abdul Rahman Embong Bangi (ed.) (1995), Antropologi dan Sosiologi Menggaris Arah Baru) dan Pengajian Melayu (Lihat Zahir Ahmad (ed.) (2000), Pengajian Kesusasteraan Melayu di Alaf Baru, Kuala Lumpur).

12 Sikap ini timbul antara lainnya disebabkan oleh semangat nasionalisme Melayu yang mendedahkan banyak kelemahan yang dibuat oleh penjajah British. Lihat Muhammad Abu Bakar (1993), "Pandangan Dunia, Ideologi dan Kesarjanaan: Islam, Proses Sejarah dan Rekonstruksi Realiti Sosial," dalam Tinta Kenangan, Sumbangan Sempena Persaraan dan Perlantikan Naib Canselor, Profesor Datuk Mohd Taib Osman, Kuala Lumpur: DBP, hlm 312-314. 
Pendekatan Baru Maqasid al-Shariah Dalam Pengajian Syariah di Malaysia

sistem dan pendekatan penyelidikan ala Barat. ${ }^{13}$ Pendekatan ini kemudiannya telah terpengaruh dengan kesedaran kebangkitan Islam era 1970an yang memasukkan pendekatan Islam yang mengkritik kelemahan sistem pengajian Islam lama dan beberapa usaha reformasi memperbaiki kelemahan ini telah ditekankan, ${ }^{14}$ khususnya membabitkan tiga buah universiti di Malaysia iaitu Universiti Malaya, ${ }^{15}$ Universiti Kebangsaan Malaysia ${ }^{16}$ dan Universiti Islam Antarabangsa Malaysia. Selanjutnya idea tajdid ini turut mempengaruhi beberapa IPTS aliran Islam yang lain, walaupun dalam bentuk dan realiti yang berbeza daripada IPTA biasa. ${ }^{17}$

Mengikut pengamatan semasa, kita dapat mengesan sifat kedinamikan, terbuka dan fleksibiliti yang dimiliki oleh institusi pendidikan Islam; sentiasa mampu menanggani sebarang bentuk perubahan yang berlaku di dalam masyarakat, merangkumi isu pasca kemerdekaan, pemodenan dan globalisasi. ${ }^{18}$ Maksudnya, kalangan pengubal institusi pendidikan Islam (termasuk perundangan Islam) pasti akan mampu berhadapan

13 Muhammad Kamal Hasan (1996), "Pembentukan Ilmu Kemasyarakatan Dari Perspektif Islam" dalam Wan Hashim Wan Teh (ed.), Sains Sosial Dari Perspektif Islam, Kuala Lumpur, hlm 11-22.

14 Rahimin Affandi Abd. Rahim (1997), “Gerakan Tajdid di Malaysia: Teori dan Realiti," dalam Mahmood Zuhdi Hj. Ab. Majid (ed.), Dinamisme Pengajian Syariah, Kuala Lumpur: Berita Publishing, hlm 102-106.

15 Mohammad Azam Mohammad Adil (1994), “Pengajian Undangundang Islam di Pusat Pengajian Tinggi - Amalan Di ITM," dalam Jurnal Tasawwur Islam, V. 3, hlm 75-84

16 Abdul Aziz Bari (1999), "Legal Education and Islamization," dalam IIUM Law Journal, V. 7, No. 1, hlm 83-94.

17 Lihat Marzuki Haji Mahmood (2003), "Keberkesanan dan Sambutan Masyarakat Terhadap Pengajian Islam di Institusi Pengajian Islam," dalam Suzalie Mohamed (ed.), Memahami Isu-isu Pendidikan Islam di Malaysia, Kuala Lumpur: IKIM, hlm 179-186

18 Akh. Minhaji (2003), Masa Depan Pembidangan Ilmu di Perguruan Tinggi Agama Islam, Jogjakarta: Percetakan ar-Ruzz Jogjakarta, hlm 62-80. 
Jurnal Fiqh: No. 3 (2006)

dengan cabaran globalisasi yang sedang melanda dunia dewasa ini.

Dewasa ini, walaupun institusi pendidikan Islam sering dikaitkan dengan isu keganasan global, ${ }^{19}$ kita boleh membuktikan secara konseptual dan praktikal, bagaimana institusi pendidikan Islam mampu memberikan input keilmuan dan kemanusiaan yang positif kepada umat manusia. Hal ini boleh dilihat daripada Deklarasi Institusi Pendidikan Tinggi UNESCO yang bersesuaian dengan prinsip-prinsip Islam ataupun ajaran Islam itu sendiri mampu memenuhi ketetapan UNESCO ini. ${ }^{20}$ Butiran deklarasi ini antara lainnya;

1. tentang misi dan fungsi Perguruan Tinggi, Deklarasi menegaskan bahwa misi dan nilai pokok IPTA/IPTS adalah memberikan sumbangan kepada pembangunan yang berkelanjutan (sustainable development) dan pengembangan masyarakat secara keseluruhan. Dalam konteks itu, misi dan fungsi Perguruan Tinggi secara lebih spesifik adalah: mendidik mahasiswa dan warganegara untuk memenuhi keperluan seluruh sektor aktiviti manusia, dengan menawarkan kualifikasi-kualifikasi yang relevan, termasuk pendidikan dan pelatihan profesional yang mengkombinasikan ilmu pengetahuan dan keahlian tingkat tinggi melalui matakuliah-matakuliah yang terus dirancang, dinilai secara berterusan bagi dikembangkan untuk menjawab berbagai keperluan masyarakat dewasa ini dan masa datang.

19 Sila Lihat Rahimin Affandi Abd. Rahim, "Aliran Pemikiran Islam Moden: Satu Kajian Perbandingan," kertas kerja dibentang dalam Seminar Pengurusan Keganasan Politik di Malaysia, anjuran Maktab Pegawai Kanan PDRM, Cheras, Kuala Lumpur, pada 19hb Ogos 2003.

20 Lihat, UNESCO (1998), Higher Education in the Twenty-First Century: Vision and Action, Paris: UNESCO. 
Pendekatan Baru Maqasid al-Shariah Dalam Pengajian Syariah di Malaysia

2. memberikan berbagai kesempatan (espace ouvert) kepada para peminat untuk memperoleh pendidikan tinggi sepanjang usia. Perguruan Tinggi memiliki misi dan fungsi memberikan kepada para penuntut ilmu sejumlah pilihan yang optimal dan fleksibilitas untuk masuk ke dalam dan keluar dari sistem pendidikan yang ada. Perguruan Tinggi juga harus memberikan kesempatan bagi pengembangan individu dan mobiliti sosial bagi pendidikan kewargaan (citizenship) dan bagi partisipasi aktif dalam masyarakat. Dengan begitu, peserta akan memiliki visi yang mendunia, dan sekaligus mempunyai kapasiti membangun yang mempribumi (indigenous).

3. memajukan, menciptakan dan menyebarkan ilmu pengetahuan melalui penyelidikan; dan memberikan keahlian (expertise) yang relevan untuk membantu masyarakat umum dalam pengembangan budaya, sosial dan ekonomi; mengembangkan penelitian dalam bidang sains dan teknologi, ilmu-ilmu sosial, humaniora dan seni kreatif.

4. membantu untuk memahami, menafsirkan, memelihara, memperkuat, mengembangkan, dan menyebarkan budaya-budaya historis nasional, regional dan internasional dalam pluralisme dan keragaman budaya.

5. membantu untuk melindungi dan memperkuat nilainilai sosial dengan menanamkan kepada generasi muda nilai-nilai yang membentuk dasar kewargaan yang demokratis (democratic citizenship).

6. memberikan sumbangan kepada pengembangan dan peningkatan pendidikan pada seluruh peringkat, termasuk pelatihan para guru.

Hal tak kurang pentingnya bagian lain dari World Declaration of Higher Education yang perlu dikutip di sini 
Jurnal Fiqh: No. 3 (2006)

adalah tentang peranan etika, otonomi, tanggungjawab dan fungsi pengelibatan IPTA/IPTS. Dalam hal ini IPTA/ IPTS berkewajiban:

1. memelihara dan mengembangkan fungsi-fungsi krusialnya melalui penegakan etik dan keteguhan ilmiah dan intelektual melalui berbagai aktivitasnya.

2. mampu berbicara lantang dan tegas tentang masalah-masalah etik, kebudayaan dan sosial secara bebas dan, dengan kesadaran penuh tentang tanggungjawabnya; menegakkan otoriti intelektual yang diperlukan masyarakat dalam berefleksi, memahami, dan bertindak.

3. memperkuat fungsi-fungsi kritis dan berorientasi ke masa depan (future oriented) melalui analisis yang berkelanjutan tentang kecenderungankecenderungan perubahan dan perkembangan sosial, ekonomi, budaya dan politik yang sedang tumbuh; dan sekaligus memberikan fokus bagi prediksi, peringatan dan pencegahan.

4. menegakkan kapasiti intelektual dan prestise moralnya untuk membela dan secara aktif menyebarkan nilai-nilai yang telah diterima secara universal, termasuk perdamaian, keadilan, kebebasan, kesetaraan, dan solidaritas, seperti disinggung dalam Konstitusi UNESCO.

5. menikmati kebebasan dan otonomi akademis, seperti terlihat dalam hak-hak dan kewajiban, sementara tetap bertanggungjawab sepenuhnya (fully responsible) dan accountable kepada masyarakat.

6. memainkan peranan dalam membantu mengidentifikasi dan menjawab masalah-masalah yang mempengaruhi kesejahteraan berbagai komuniti, bangsa, dan masyarakat global.

Daripada kesemua butiran ini, khususnya yang membabitkan isu globalisasi, tanggungjawab kemanusiaan, 
Pendekatan Baru Maqasid al-Shariah Dalam Pengajian Syariah di Malaysia

kapasiti intelektual dan moral mampu dipenuhi oleh prinsip Maqasid al-Shariah. ${ }^{21}$ Tinggal lagi, berhadapan dengan tuntutan globalisasi ini, institusi pendidikan Islam perlu melakukan beberapa perkara yang penting;

Pertama, menolak sebarang bentuk tindakan keganasan dalam kurikulum institusi pendidikan Islam. ${ }^{22}$ Konsep jihad yang sering disalahfahamkan perlu dijauhkan sama sekali. ${ }^{23}$ Seperti mana ditegaskan oleh Feisal Abdul Rauf, umat Islam perlu menghadapinya dengan cara dan kaedah yang cukup berhikmah agar ianya tidak sampai kepada memburukkan lagi keadaan yang memang sebelumnya telahpun buruk. ${ }^{24}$ Hal ini dapat dilakukan antara lainnya dengan kembali menghidupkan kerangka intelektualisme Islam, yang suatu masa dahulu dilaporkan pernah menghasilkan benih yang cukup gemilang di dalam melahirkan tamadun material dan intelektual umat Islam, ${ }^{25}$ sehingga kemudiannya telah mempengaruhi pembangunan tamadun Barat itu sendiri. ${ }^{26}$

Kedua, kepentingan menggunakan pendekatan pertengahan di dalam menanggani isu globalisasi. Pendekatan yang dimaksudkan adalah tidak terlalu anti

21 Very Verdiansyah (2004), Islam Emansipatoris: Menafsir Agama Untuk Praksis Pembebasan, Jakarta: P3M, hlm 158-162.

22 Lihat sebagai contohnya Hashim Musa (2004), Pemerkasaan Tamadun Melayu Malaysia Menghadapi Globalisasi Barat, Kuala Lumpur: Penerbit UM, hlm 232.

23 Lihat Zulkifli Haji Mohd Yusoff dan Fikri Mahmud, “Jihad dan Imej Keganasan: Satu Analisa Tentang Prinsip Jihad Dalam al-Quran," dalam Prosiding Islam: Past, Present and Future-International Seminar on Islamic Thoughts, anjuran bersama Jabatan Usuluddin dan Falsafah, UKM dengan Jabatan Hal Ehwal Khas, Kementerian Penerangan Malaysia, pada 7-9hb. Disember 2004.

24 Feisal Abdul Rauf (2002), Islam: A Sacred Law: What Every Muslim Should Know About Shariah, Kuala Lumpur: YADIM, hlm 24-25.

25 Ozay Mehmet (1990), Islamic Identity and Development: Studies of Islamic Periphery, Kuala Lumpur: DBP, hlm 36-38.

26 Mahmud Hamdi Zaqzuq (1989), Orientalisme: Kesan Pemikirannya Terhadap Tamadun Islam, Kuala Lumpur: DBP, hlm 10-20. 
Jurnal Fiqh: No. 3 (2006)

dan tidak pula terlalu menyokong agenda globalisasi ini secara membuta tuli. Mengikut reformis Melayu semasa, pendekatan pertengahan ini perlu diambil kerana pada dasarnya idea asas globalisasi ini bersesuaian dengan sifat dan falsafah ajaran Islam itu sendiri yang menganjurkan beberapa elemen global seperti; ${ }^{27}$

1. Islam adalah untuk semua manusia tanpa mengira perbezaan ras

2. Allah adalah penguasa seluruh alam

3. penekanan kepada konsep ummah, kesatuan akidah seluruh umat Islam sedunia

4. galakan Allah supaya manusia menjelajahi dunia

5. galakan ke arah penguasaan ilmu dan kefahaman yang bersifat global

6. penekanan kepada konsep hak asasi manusia yang lebih jitu dan adil

7. penekanan kepada penjagaan alam sekitar yang bersifat mampan. ${ }^{28}$

Realiti fenomena globalisasi juga telah memungkinkan proses penyebaran maklumat khususnya tentang sesuatu agama menjadi lebih terbuka dan boleh diperolehi oleh sesiapa sahaja. Dengan datangnya era globalisasi, bentuk perhubungan masyarakat dunia telah berubah dengan wujudnya reruang siber/reruang maya (virtual reality) yang tidak pernah berlaku sebelumnya dalam sejarah manusia. Reruang siber ini dinyatakan sebagai; "ruang

27 Lihat Zainuddin Jaffar (2000), Spektrum Pemikiran Islam, Bangi Lama: KISDAR, hlm 19-22; Lihat juga Siddiq Fadzil (2001), "Ledakan Maklumat, Revolusi Komunikasi dan Globalisasi: Implikasi Terhadap Jati Diri," dalam (edit oleh Sharifah Azizah Sahil Jamalullail), Teknologi Maklumat dan Komunikasi: Harapan, Cabaran dan Barakah, Alor Setar: INSANIAH, hlm 62-65.

28 Mohd Zuhdi Marsuki dan Amer Saifude Ghazali (2002), Etika Alam Sekitar Daripada Perspektif Islam, Timur dan Barat, Kuala Lumpur: PTS, hlm 118-135. 
atmosfera atau ruang udara yang mengandungi jisim dan jirim yang menjadi laluan gelombang cahaya dan bunyi sebagai medan penghantaran maklumat serta laluan untuk berkominikasi. Ianya dimanfaatkan untuk sistem komunikasi sama ada dengan menggunakan wayar ataupun tidak. Ia adalah jaluran lebuh raya maklumat yang boleh melampaui batasan jarak, sempadan, masa dan tempat apabila digunakan untuk berkomunikasi." 29

Tambah penulis ini lagi; “Kelahiran reruang siber ini mempercepatkan lagi proses mentamadunkan pemikiran manusia kerana melaluinya penyebaran dan proses transformasi maklumat lebih mudah dan cepat. Kesan kewujudan reruang siber melalui falsafah cyborg ini telah melahirkan masyarakat baru (online) yang berbeza daripada masyarakat massa (industri). ${ }^{30}$ Fenomena ini antara lainnya bakal membolehkan setiap penganut agama mengetahui dan memahami sesuatu ajaran agama lain dengan lebih mendalam lagi daripada sumber yang betul, tanpa dipengaruhi oleh sesuatu pandangan yang bersifat berat sebelah. ${ }^{31}$

Apa yang cukup menguntungkan, era globalisasi juga telah mewujudkan dimensi dakwah yang lebih luas lagi. Hal ini terbukti dengan realiti tersebarnya pelbagai buku dan laman web tentang agama Islam ${ }^{32}$ yang menerangkan

29 Jalaluddin Abdul Malek (2002), "Falsafah Reruang Siber dan Komuniti Online: Cabaran Pembangunan Alaf Baru," dalam Misran Rokimin (ed.), Falsafah dan Peradaban Pembangunan, Bangi: Penerbit UKM, hlm 86-87.

30 Ibid.

31 Abdullah Embong (2001), "Sistem Maklumat Islam: Cabaran dan Keperluan Maklumat Umat Islam di Malaysia Dari Perspektif Agama," dalam Teknologi Maklumat dan Komunikasi: Harapan, Cabaran dan Barakah, Alor Setar: INSANIAH, hlm 124-134.

32 Antara homepage Islam yang cukup terkenal menggunakan pendekatan ini adalah Kampung Net-Singapore Muslim Community Page, Japan Islamic Network dan About al-Islam and Muslims. Lihat "Islam Dalam Internet," Dalam Majalah PC, Jilid 5, V. 1, 1996, hlm 29. 
Jurnal Fiqh: No. 3 (2006)

tentang sikap ajaran Islam yang menentang keras sebarang bentuk amalan ekstremisme yang melampau. ${ }^{33}$ Seperti dijelaskan oleh seorang sarjana Islam, selepas peristiswa 11 September, masyarakat Barat telah berusaha mengkaji ajaran Islam daripada sumbernya yang betul, Quran dan Sunnah. Hasilnya, sebahagian besar masyarakat Barat merasa hairan kerana sebahagian besar daripada ajaran Islam didapati penuh dengan sifat rahmah (nilai kemanusiaan) yang amat baik, ${ }^{34}$ kemuncaknya boleh dilihat dengan bertambah ramai masyarakat Barat yang telah memeluk agama Islam. ${ }^{35}$

Mengikut kupasan Chandra Muzaffar, pengaruh fenomena globalisasi terhadap peradaban hidup manusia moden adalah agak rencam; terdapat elemen positif dan negatif. Beliau telah menyenaraikan lapan kebaikan globalisasi, tetapi senarai keburukannya lebih banyak, iaitu sebanyak tiga belas elemen keburukan. Elemen kebaikan ini antara lainnya terdiri dari; ${ }^{36}$

1. Peranan pelaburan asing (FDI) dalam mewujudkan pekerjaan dan mengurangkan kemiskinan di sebilangan negara.

2. Peningkatan mobiliti sosial dan pengukuhan kelas menengah (intelektual).

33 Fadhlullah Jamil (2001), “IT, Perkembangannya dan Kesannya Terhadap Umat Islam," dalam Teknologi Maklumat dan Komunikasi: Harapan, Cabaran dan Barakah, Alor Setar: INSANIAH, hlm 54-55.

34 Lihat Mohd. Azizuddin Mohd. Sani (2002), Hak Asasi Manusia Menurut Pandangan Islam dan Barat, Kuala Lumpur: Penerbitan PTS, hlm 52-58.

35 Gordon D. Newby (1996), “Muslim/Non-Muslim Relations: Lesson From the Past for a Better Future," dalam Aidit Haji Ghazali (ed.), Development, Islamic, Malaysian and American Perspectives, Kuala Lumpur: INMIND, hlm 49-50.

36 Chandra Muzaffar, "Globalisation and Religion: Some Reflection," dalam Joseph A. Camilleri (ed.) (2001), Religion and Culture in Asia Pacific: Violence or Healing, Melbourne: Vista Publication, hlm 180-186. 
Pendekatan Baru Maqasid al-Shariah Dalam Pengajian Syariah di Malaysia

3. Peluang yang lebih luas untuk mendapatkan maklumat dan menyebarkan ilmu pengetahuan berkat teknologi baru komunikasi.

4. Komunikasi yang lebih mudah dan murah.

5. Peluang yang lebih luas untuk manusia dari pelbagai kumpulan etnik, budaya dan agama berinteraksi.

6. Peluang lebih luas untuk menzahirkan simpati dan rasa peri kemanusiaan terhadap mangsa pelbagai jenis bencana alam dan tragedi buatan manusia.

7. Penonjolan idea-idea dan amalan pemerintahan yang lebih baik seperti pertanggungjawaban awam, peraturan undang-undang dan hak asasi manusia.

8. Penonjolan hak-hak asasi kaum wanita.

Apa yang boleh dilihat daripada senarai ini iaitu kesedaran manusia tentang kepentingan hidup bersama, diharapkan ianya akan mampu memperbetulkan semua elemen keburukan yang dihasilkan oleh fenomena globalisasi. $^{37}$

Ketiga, keperluan mengamalkan pendekatan yang selektif terhadap prinsip hak asasi manusia ala Barat yang sering disamakan dengan konsep Maqasid al-Shariah. ${ }^{38}$ Mengikut kupasan para fuqaha Islam, kepentingan manusia dan masyarakat yang dijamin oleh syariah Islam didorong dengan empat intipati yang utama;

1. Jalb al-Masalih - mencapai kepentingan di dalam kehidupan.

2. Dar al-Mafasid - menolak kerosakan yang bakal timbul dalam masyarakat.

37 Osman Bakar (2003), "Globalisasi dan Peradaban," dalam A. Aziz Deraman, Globalisasi Dalam Peradaban di Malaysia, Kuala Lumpur: DBP, hlm 33-38.

38 Lihat Mohd. Azizuddin Mohd. Sani (2002), Hak Asasi Manusia Menurut Pandangan Islam dan Barat, Kuala Lumpur: Utusan Publication, hlm 52-58. 
Jurnal Fiqh: No. 3 (2006)

3. Sadd al-Dharar - menyekat kepentingan buruk.

4. Taghayyur al-Zaman - mementingkan faktur peredaran zaman.

Merujuk kepada perkara yang (1), matlamat utama hukum Islam adalah bagi memelihara kemaslahatan (kepentingan) masyarakat yang terbahagi kepada tiga bentuk kepentingan; ${ }^{39}$

1. Maslahah asas (Daruriyyah) yang melibatkan pemeliharaan lima perkara iaitu agama, jiwa, akal, kehormatan dan harta. Kesemua kepentingan ini dapat dianggap sebagai keperluan asasi yang tidak dapat tidak amat diperlukan oleh setiap manusia, di dalam kehidupan bermasyarakat. Seandainya salah satu daripada keperluan ini tidak dipenuhi, kehidupan manusia sudah tiada ertinya lagi. Sebarang perkara dan tindakan yang mencabul kelima-lima perkara ini akan dianggap sebagai mafsadah.

2. Maslahah yang diperlukan (Hajiyyah) yang melibatkan semua yang diperlukan oleh manusia untuk mewujudkan kemudahan dan kelapangan dalam menjalankan tugas dalam kehidupan. Walaupun ianya tidak sampai kepada tahap keperluan asasi yang boleh menyebabkan kebinasaan hidup manusia, tetapi ianya diperlukan bagi mengelakkan kesusahan hidup di dalam masyarakat.

3. Maslahah yang diperlukan untuk menjaga kehormatan hidup manusia (Tahsiniyyah) yang melibatkan kemuliaan akhlak dan adat yang baik. Semuanya diperlukan bagi menjamin kelancaran hidup manusia dalam masyarakat.

39 Mahmood Zuhdi Ab Majid dan Paizah Ismail (2004), Pengantar Pengajian Syariah, Kuala Lumpur: al-Baian Corporation Sdn Bhd, hlm 187-189. 
Pendekatan Baru Maqasid al-Shariah Dalam Pengajian Syariah di Malaysia

Jika dilihat kepada ruang lingkup kepentingan yang cuba dipelihara oleh syariah Islam, secara jelasnya kepentingan ini terbahagi kepada tiga bahagian;

1. Kepentingan awam masyarakat terbanyak - ianya perlu sentiasa dijaga dan diutamakan dalam setiap pensyariatan hukum Islam.

2. Kepentingan orang kebanyakan - ianya perlu dijaga demi untuk memastikan kebajikan masyarakat awam.

3. Kepentingan orang perseorangan - ianya perlu dijaga selama mana tidak menjejaskan kepentingan masyarakat awam dan tidak bertentangan dengan lunas-lunas Islam.

Kesejahteraan dan kebahagiaan seseorang individu dan masyarakat akan terjamin seandainya ketiga-tiga Maslahah ini dapat dipenuhi dengan cara yang seimbang. Penetapan konsep Maslahah ini di dalam hidup bermasyarakat secara terang-terangan telah mendahului konsep penjagaan hak asasi manusia yang hanya timbul di dalam dunia Barat dalam konteks zaman moden ini, akibat daripada kesedaran manusia terhadap kemusnahan yang berlaku kerana Perang Dunia Pertama dan Kedua.

Konsep Maslahah ini berbeza dengan konsep kepentingan awam (hak asasi manusia) yang ditekankan dalam kerangka masyarakat Barat. Kepentingan awam yang sering dijadikan rujukan dalam masyarakat Barat biasanya merujuk kepada beberapa perkara yang bertentangan dengan garis panduan Islam, yang terdiri dari; $; 0$

1. Kepentingan awam yang berasaskan paradigma sekularisme Barat berteraskan falsafah Hedonisme (nafsu manusia sebagai neraca tertinggi untuk

40 Lukman Thaib (1998), Politik Menurut Perspektif Islam, Kuala Lumpur: Synergymate Sdn Bhd, hlm 30-38. 
Jurnal Fiqh: No. 3 (2006)

sesuatu nilai), Modernisme, Pragmatisme, Nasionalisme sempit dan sebagainya.

2. Kepentingan awam yang berteraskan pengambilkiraan elemen keduniaan semata-mata tanpa pertimbangan akhirat.

3. Kepentingan awam yang berasaskan kepada tren kegemaran sesuatu masyarakat semasa walaupun ianya bertentangan dengan lunas keagamaan, seperti tren yang mengakui amalan free-sex dan homoseksual.

4. Kepentingan awam yang diwakili oleh majoriti masyarakat akan dianggap sebagai otoriti tertinggi yang perlu dihormati. Dalam Islam, neraca kebenaran bukan tertakluk kepada nisbah dan jumlah sokongan rakyat terbanyak. Maksudnya, jumlah majoriti itu tidak semestinya betul dan minoriti juga tidak semestinya salah.

Atas dasar inilah fuqaha telah meletakkan beberapa syarat khusus untuk pengamalan konsep maslahah ini. Hal ini ditetapkan agar ianya tidak disalahgunakan untuk kepentingan awam yang lebih kurang sama dengan pendekatan ala Barat. Syarat-syarat ini antaranya; ${ }^{41}$

1. Tidak bertentangan dengan nas Quran dan Sunnah jelas dan terang (qat'i).

2. Tidak bertentangan dengan prinsip qiyas.

3. Harus dilakukan oleh fuqaha yang kompeten ataupun perlu mengambilkira pandangan fuqaha, yang memahami rahsia dan matlamat (Maqasid Syariah) setiap hukum syariah yang diturunkan kepada manusia.

4. Ketiga Maslahah adalah bersifat integratif dan saling melengkapi antara satu sama lain.

41 Amir Muallim dan Yusdani (1999), Konfigurasi Pemikiran Hukum Islam, Yogyakarta: UII Press, hlm 39-43. 
Pendekatan Baru Maqasid al-Shariah Dalam Pengajian Syariah di Malaysia

5. Tidak diambilkira maslahah Hajiyyah dan Tahsiniyyah seandainya perkara yang dilakukan akan membawa kepada pembatalan terhadap maslahah Daruriyyah.

6. Harus mengutamakan maslahah yang lebih penting dan besar, yang dapat dibuat dengan;

a. Memandang nilai maslahah dari segi zatnya mengikut skema hiraki maslahah Daruriyyah yang tersusun; agama, nyawa, akal, keturunan dan harta.

b. Memandang maslahah dari segi bidang cakupan - demi untuk menjaga maslahah keturunan, kepentingan maslahah masyarakat secara kolektif perlu diutamakan.

c. Memandang maslahah dari segi akibatnya seandainya sesuatu perbuatan ingin dilakukan bagi menjaga sesuatu maslahah, tetapi dapat diramal bahawa hal ini akan menimbulkan mafsadah (kerosakan dan kemaksiatan), maka aspek ramalan yang berasas ini perlu diutamakan.

Keempat, kalangan pengubal IPTA/IPTS aliran Islam di Malaysia perlu memikirkan kaedah dan pedagogi terbaik untuk melaksanakan butiran UNESCO/prinsip Maqasid alShariah ini di dalam pengajaran yang membabitkan pengajian syariah di Malaysia.

\section{ANALISIS PENDEKATAN BARU DALAM KONSEP DAN APLIKASI MAQASID AL-SHARIAH DI DALAM PENGAJIAN SYARIAH; PENGALAMAN APIUM}

Dalam bahagian ini, penerangan khusus tentang aspek konsep dan aplikasi reformasi Maqasid al-Shariah dalam pengajaran syariah akan dipecahkan kepada dua bahagian yang utama; (i) secara makro tentang bagaimana 
Jurnal Fiqh: No. 3 (2006)

sepatutnya pengajian syariah dijalankan dan (ii) secara mikro membabitkan usaha yang telah dijalankan oleh APIUM di dalam menerapkan prinsip Maqasid al-Shariah dalam pengajian syariah.

Secara makronya, terdapat beberapa perkara yang perlu dilakukan untuk memperkasakan pendekatan pengajian syariah, khususnya yang membabitkan prinsip Maqasid al-Shariah di dalam disiplin usul al-fiqh. Hal ini antara lainnya terdiri dari;

Pertama, membuat review dan pengkajian ulang tentang bentuk dan sistem pengajian syariah yang sepatutnya diterapkan ke dalam masyarakat, dengan menjadikan disiplin usul al-fiqh sebagai asas utama pengajaran bagi memperlihatkan kedinamisan disiplin usul al-fiqh ini di dalam memperkembangkan pengajian syariah di setiap zaman yang berbeza. Dalam soal ini, apa yang lebih penting lagi, subjek utama pengajaran perlu bertumpu kepada mekanisme bagaimana disiplin ini boleh dipakai untuk konteks zaman moden menggunakan prinsip-prinsip usul al-fiqh yang terbaru dengan pendekatan yang bersifat semasa dan sesuai dengan realiti tempatan Malaysia. ${ }^{42}$

Mengikut pengamatan yang dilakukan oleh Lukman S. Tahir, terdapat dua tren yang biasanya dipakai oleh fuqaha di dalam melihat persoalan agama dengan masyarakat. Kedua-dua tren ini antara lain; 43

1. Tren transcendental-spekulatif; tren yang meletakkan tuhan sebagai kuasa unggul dan terlepas dari dunia realiti yang membabitkan masyarakat. Tuhan digambarkan sebagai lebih bersifat metafizik dan

42 Intipati pendekatan ini boleh didapati dalam Mahmood Zuhdi Ab Majid dan Paizah Ismail (2004), Pengantar Pengajian Syariah, Kuala Lumpur: al-Baian Corporation Sdn Bhd.

43 Lukman S. Tahir (2004), Studi Islam Interdisipliner: Aplikasi Pendekatan Filsafat, Sosiologi dan Sejarah, Yogyakarta: QIRTAS, hlm 133-141. 
Pendekatan Baru Maqasid al-Shariah Dalam Pengajian Syariah di Malaysia

tidak menyentuh dimensi kemanusiaan yang serba tidak sempurna. Bagi menanggani tren ini, beliau mencadangkan agar sarjana Islam bukan setakat membincangkan soal kekuasaan tuhan yang maha mutlak, tetapi perlu juga memikirkan bagaimana kaedah terbaik untuk menyerap dan meniru beberapa sifat tuhan yang serba sempurna secara fungsional untuk dilaksanakan di dalam kehidupan bermasyarakat.

2. Tren a histories dan deduktif-monolitik; yang memandang Islam yang dipelajari bukan Islam pada masa sekarang tetapi lebih menyentuh isu Islam di zaman awal dan pertengahan Islam. Oleh sebab itu, sebagai pendekatan proaktif, institusi pengajian Islam perlu menggunakan perndekatan yang mengambil kira realiti semasa dengan perkiraan ilmu moden. Lebih tepat lagi, warisan silam hanya patut dihargai dan dijadikan sebagai asas precedent untuk kajian umat Islam semasa. Dalam soal ini juga, kita tidak sepatutnya memandang negatif terhadap isu pemodenan. Bagi sesetengah sarjana Islam moden, agama Islam itu sendiri amat bersifat moden, yang boleh dilihat daripada beberapa ciri yang utama; ${ }^{44}$

- Menekankan pemusatan kepada manusia yang terpimpin bersesuaian dengan lunas-lunas Islam (bertentangan dengan pendekatan Barat yang meletakkan manusia dan nafsunya sebagai pusat segala perkara).

- Menekankan pembentukan manusia yang berasaskan kerangka etos Islam yang memiliki tanggungjawab dan jujur di dalam hubungan dengan manusia dan alam.

44 Lihat H. Syahrin Harahap (1999), Islam; Konsep dan Implementasi Pemberdayaan, Yogyakarta: PT Tiara Wacaana Yogya, hlm 11-25. 
Jurnal Fiqh: No. 3 (2006)

- Mengalakkan penyertaan masyarakat sama ada golongan majoriti ataupun minoriti di dalam perjalanan sesuatu institusi kerajaan.

- Menunda kesenangan jangka pendek untuk kesenangan jangka panjang.

- Memanfaatkan waktu dan etos kerja yang cemerlang

- Yakin dengan keadilan dapat disebarkan kepada manusia

- Menekankan pengamalan budaya ilmu sebagai kaedah untuk melahirkan kreatifiviti akal yang tinggi.

- Menyanjung tinggi bakat dan kemampuan serta penghargaan diberikan berdasarkan prestasi dan bukannya berasaskan kepada paradigma feudalisme.

Kedua, menyedari tentang kelemahan pendekatan kajian hukum Islam yang bersifat legal formalistik. Pada kebiasaannya, sesuatu kajian yang membabitkan analisis hukum Islam yang diusahakan oleh fuqaha Islam lebih bersifat legal formalistic (halal ataupun haram), yang menyebabkan kupasannya lebih bersifat kaku dan cenderung kepada tindakan menghukum dan bukannya bersifat konstruktif bagi mendidik golongan sasaran kajian, anggota masyarakat. ${ }^{45}$ Sebaiknya, sarjana Islam perlu memikirkan untuk menggunakan pendekatan kajian yang lebih terbuka dan holistic (menyeluruh) dalam proses penilaian sesuatu persoalan hukum Islam. ${ }^{46} \mathrm{Hal}$ ini bersesuaian dengan tren perubahan paradigma keilmuaan

45 Very Verdiansyah, Islam Emansipatoris: Menafsir Agama Untuk Praksis Pembebasan, hlm 126-127.

46 Dalam konteks Malaysia semasa, usaha untuk mewujudkan kerangka penyelidikan ilmiah dalam bidang pengajian Islam yang berorientasikan elemen saintifik (gabungan antara logik dan S\&T) boleh dikatakan masih terlalu baru, yang perlu terus dibangunkan. Namun begitu, ianya telah cuba dicetuskan oleh Abdul Latif Samaian, Idris Awang, Shafi'e Abu Bakar, Mohd Fauzi Hamat, Hairudin Harun dan ramai lagi sarjana Malaysia yang lain. 
yang secara lantang disuarakan oleh banyak pihak. Ianya terdiri dari pendekatan; ${ }^{47}$

1. Mechanism; pendekatan yang lebih terbuka berbanding pendekatan legal formalistic (formism), yang memberikan penekanan kepada sifat pokok sesuatu mechanisme iaitu soal kontinuiti dan mekanis. Menurut paradigma ini semua gejala kehidupan adalah bersifat bersinambungan dalam proses mekanis yang terus bergerak. Ianya paling disesuai diterapkan dalam kerangka kajian yang membabitkan elemen kemasyarakatan, memandangkan masyarakat manusia bukannya statik dan selalu berubah, sama ada ke arah yang lebih baik ataupun sebaliknya.

2. Organism; seluruh realiti kehidupan pada dasarnya berjalan secara harmonis, integrated, penuh perkaitan antara faktor dalaman dan luaran serta penuh dengan kepastian. Atas dasar ini, kaedah terbaik untuk memahami realiti kehidupan manusia perlu mengabungkan kesemua bentuk disiplin keilmuan, seperti sejarah, sosiologi, ekonomi dan sebagainya.

3. Pragmatism; semua fenomena kemanusiaan yang dikaji adalah bersifat kontekstual, tidak ada satupun dalam kehidupan ini yang tidak berkait dengan konteks dan kondisinya yang bersifat khusus. Atas dasar ini, kajian terhadap elemen manusia akan menjadi lebih mendalam sekiranya dilihat kepada aspek konstektual sesuatu objek yang dikaji.

Bukan setakat kalangan fuqaha Islam, kelemahan yang sama turut dialami oleh sesetengah kalangan yang terdidik melalui sistem pendidikan sekular, yang kononnya telah

47 Prof Dr Mastuhu (1998), “Penelitian Agama Islam: Perspektif Antar Disiplin Ilmu: Tinjauan Disiplin Sosiologi," dalam Mastuhu (ed.), Tradisi Baru Penelitian Agama Islam: Tinjauan Antar-Disiplin Ilmu, Bandung: Penerbit Nuansa, hlm. 91-104 
Jurnal Fiqh: No. 3 (2006)

mengajarkan paradigma pemikiran moden. Mengulas kelemahan pendekatan sekularis dan tradisionalis melampau, Mahmood Zuhdi dan Amir Mualim memperincikan beberapa kekeliruan ilmu yang secara langsung menjejaskan pemahaman mereka terhadap hakikat hukum Islam yang sebenar. Ianya merangkumi; 48

i. Subjektiviti; mengambil sikap tertentu yang tidak matang terhadap sesuatu nas akibat kejahilan memahami Islam secara holistic.

ii. Manipulasi; melepaskan dalil syarak dari situasi dan kondisi semasa sesuatu nas syarak di turunkan.

iii. Justifikasi; tindakan menundukkan nas syarak agar bersesuaian dengan realiti yang ada ataupun mencari pembenaran terhadap praktik baru dengan cara menundukkan nas syarak kepada penafsiran yang sesuai.

iv. Interpolasi; memasukkan nas ke dalam kerangka berfikir tertentu, seperti faham sosialisme yang telah secara kuat dipegang oleh seseorang yang memang bertentangan dengan prinsip Islam.

v. Inakurasi; sikap ketidaktahuan dan ketidaktelitian berpegang kepada nas yang tidak valid dan tidak relevan dalam menanggani sesuatu persoalan yang timbul.

Dalam contoh yang lain, Amin Abdullah telah menekankan peri pentingnya dilakukan proses reviewing (ulangkaji) terhadap pendekatan penyelesaian masalah yang biasanya dipakai dalam kajian keilmuan Islam, termasuklah dalam bidang hukum Islam. Baginya, terdapat tiga bentuk tren penyelesaian masalah yang biasanya digunakan;

48 Amir Mualim (2004), Ijtihad dan Legislasi Muslim Kontemporer, Yogyakarta: UII Press, hlm. 54-56. 
Pendekatan Baru Maqasid al-Shariah Dalam Pengajian Syariah di Malaysia

i. Deduktif (sangat menekankan pengantungan kepada sesuatu nas),

ii. Induktif (ilmu yang bersumberkan kepada realiti sejarah yang difikirkan dan disusun oleh manusia)

iii. Abductive (pendekatan yang bersifat logic of discovery dan bukannya logic of justification).

Bagi Amin Abdullah, tren abductive ini sangat sesuai digunapakai untuk konteks kajian keislaman moden, memandangkan ianya menggunakan kerangka filsafat, yang terdiri dari enam langkah yang utama; (1) pengenalan latar belakang masalah, (2) pembentukan hipotesis, (3) interpretasi terhadap teori, (4) proses pengujian di lapangan terhadap sesuatu teori sarjana awal, (5) penganalisaan yang menggunakan kaedah induktif dan deduktif dan akhirnya (6) proses pengambilan kesimpulan. Dengan cara ini, sarjana zaman moden boleh melihat dengan jelas sama ada sesuatu pandangan ataupun qaul yang dikemukakan oleh fuqaha silam itu masih relevan ataupun tidak dengan kehendak dan realiti zaman moden. ${ }^{49}$

Ketiga, peri pentingnya diterapkan pendekatan kajian usul al-fiqh dalam bentuk yang baharu. Sejumlah besar sarjana moden menyuarakan kepentingan untuk memahami disiplin usul al-fiqh dalam konteks yang lebih luas lagi tidak seperti mana biasa difahami di dalam kerangka pemahaman klasik. ${ }^{50}$ Bagi Akh Minhaji, ianya

49 Amin Abdullah, “Kajian Ilmu Kalam Di IAIN: Menyongsong Perguliran Paradigma Keilmuan Keislaman Pada Era Milenium Ketiga," Dalam al-Jamiah, No. 65/VI/2000, hlm 84-88.

50 Hal ini jelas terbukti apabila UIN Sunan Kalijaga, Yogyakarta cuba mengasaskan suatu bentuk kajian Usul al-Fiqh yang lebih bersifat moden, yang digelar sebagai Usul al-Fiqh mengikut Mazhab Jogja. Maklumat lanjut boleh didapati dalam (edit oleh Riyanto) (2004), Neo Usul Figh: Menuju Ijtihad Kontekstual, Yogyakarta: Fakultas Syariah Press. 
Jurnal Fiqh: No. 3 (2006)

perlu difahami sebagai ilmu yang mempelajari dasar, metode, pendekatan dan teori yang digunakan dalam memahami ajaran Islam. ${ }^{51}$ Atas dasar inilah, ia dikatakan sebagai "queen of Islamic sciences." Hal ini bertepatan dengan pandangan Taha Jabir yang menyatakan; "usul alfigh is rightly considered to be the most important method of research ever divised by Muslim thought. Indeed as the solid foundation upon which all Islamic disciplines are based, usul alfigh not only benefited Islamic civilization but contributed to the intellectual enrichment of world civilization as a whole." 52 Pandangan ini juga menegaskan bahawa kegunaan usul alfiqh sepatutnya tidak dihadkan kepada persoalan hukum Islam semata-mata, tetapi patut dilanjutkan penggunaannya kepada bidang di luar hukum Islam.

Lanjutan daripada pandangan ini, beliau menyatakan bahawa disiplin usul al-fiqh ini bukan sebagai ilmu yang statik, tertutup dan telah disempurnakan oleh fuqaha silam yang mustahil untuk ditokok tambah oleh fuqaha yang terkemudian. Sebagai suatu disiplin ilmu, ia perlu sentiasa berkembang mengikut peredaran zaman. Ringkasnya, bersesuaian dengan konsep ilmu itu sendiri, yang boleh diujikaji, dinilai kembali dan diperkemaskan oleh sarjana di dalam zaman yang berbeza, hal yang sama perlu diterapkan kepada disiplin usul al-fiqh ini. Contoh yang mendokong pandangan ini boleh dilihat daripada perbincangan fuqaha silam, yang bermula dengan teori Amal penduduk Madinah (dibawa oleh Imam Malik), teori Ra'y (dibawa oleh Imam Abu Hanifah), teori Ijtihad-Qiyas (Imam Shafi'i), teori maslahah (dibawa oleh Shatibi) dan banyak lagi teori lain tentang pendekatan di dalam usul al-

51 Akh Minhaji (2002), "Persoalan Gender Dalam Perspektif Metodologi Studi Hukum Islam," dalam (edit oleh Siti Ruhaini Dzuhayatin), Rekonstruksi Metodologis Wacana Kesetaraan Gender Dalam Islam, Yogyakarta: Pustaka Pelajar Offset, hlm 200-207.

52 Taha Jabir al-'Alwani (1990), Usul al-Figh al-Islami, Virginia: IIIT, hlm xi. 
fiqh yang dikemukakan oleh fuqaha Islam sepanjang zaman. ${ }^{53}$ Kesemua teori-teori ini menunjukkan bagaimana fuqaha Islam memahami tentang sifat kesemasaan disiplin usul al-fiqh ini yang mengalakkan dan mengakui faktur penggunaan daya intelektualisme seseorang fuqaha di dalam menghadapi masalah kehidupan sezaman. Walaupun teori-teori baru di dalam disiplin usul al-fiqh ini sentiasa berkembang, tetapi fungsinya adalah sama iaitu untuk menterjemah wahyu Allah (paradigma tekstual) bagi menjawab persoalan hukum yang timbul di dalam masyarakat (paradigma kontekstual). ${ }^{54}$

Apa yang lebih penting lagi, kalangan pengubal IPTA/ IPTS aliran Islam memasukkan didalam kurikulum pengajian syariah semua pandangan dan teori terbaharu yang menyentuh tentang ilmu usul al-fiqh yang dikemukakan oleh pemikir dan fuqaha Islam terkini. Hal ini bakal menimbulkan sikap proaktif dan keberanian di kalangan pelajar pengajian syariah tentang bentuk reformasi yang boleh dan telahpun cuba diterapkan kepada ilmu usul al-fiqh, yang seterusnya memerlukan pengkajian, penjanaan dan pengembangan mana-mana teori baru yang sesuai untuk memperkasakan lagi disiplin ini. Antara teori-teori ini adalah seperti teori double movement yang dikemukakan oleh Fazlur Rahman, ${ }^{55}$ teori muqaranah alMazahib oleh Mahmud Shaltut, ${ }^{56}$ teori ijtihad insya'i dan intiqa'i oleh Yusuf Qaradawi, ${ }^{57}$ teori teks dan kontekstualnya oleh Ali Syariati, ${ }^{58}$ Mahmud Muhammad

53 Akh Minhaji (2002), op.cit., hlm 200-206.

54 Ibid.

55 Fazlur Rahman (1984), Islam and Modernity: Transformation of an Intellectual Tradition, Chicago: The University of Chicago Press.

56 Mahmud Shaltut (t.t.), al-Islam: Aqidah wa Syariah, Kaherah: Dar alQalam.

57 Yusuf Qardawi (t.t), Al-Ijtihad fi al-Shariah al-Islamiyyah $M a^{\prime} a$ Nazarat Tahliliyyah Fi al-Ijtihad al-Mua'sir, Kuwait: Dar al-Qamm.

58 Ali Syariati (1979), On the Sociology of Islam, Terj. Hamid Alqar, Berkeley: Mizan Press. 
Jurnal Fiqh: No. 3 (2006)

Taha dengan teori nasakh, ${ }^{59}$ teori al-Turath wa al-Tajdid oleh Hassan Hanafi, ${ }^{60}$ teori Takwil dan Tadwin oleh Nasr Hamid Abu Zayd, ${ }^{61}$ teori logosentrisme oleh Muhammad Arkoun, ${ }^{62}$ teori hudud (batas) oleh Muhammad Syahrur ${ }^{63}$ dan teori model pemikiran bayani, burhani dan irfani oleh al-Jabiri. ${ }^{64}$ Walaupun diakui tidak semua daripada teoriteori ini sesuai dipakai untuk konteks Malaysia, tetapi sekurang-kurangnya ianya bakal menunjukkan tentang sifat kelewusan dan dinamisme yang terdapat di dalam pemikiran hukum Islam semasa. ${ }^{65}$

Keempat, mengabungkan tiga bentuk pola pemikiran dalam kajian keilmuan Islam. Berasaskan kepada kupasan Abid Jabiri ini, proses pembangunan keilmuan Islam telah menggunakan tiga pola pemikiran yang utama yang digunakan secara terpisah dan tidak dijalinkan secara bersepadu. Ketiga-tiga pola ini adalah;

(1) pendekatan Bayani yang menjadi asas utama kepada pemikiran fiqh Islam. Pola ini lebih menumpukan perhatian kepada teks Quran dan sunnah yang dianggap sebagai sumber kebenaran mutlak. Akal dianggap lebih bersifat sekunder di dalam menjelas dan membela teks yang wujud. Kekuatan pendekatan ini lebih memberikan perhatian kepada aspek gramatik dan sastera Arab. Untuk

59 Mahmud Muhammad Taha (1987), The Second Messages of Islam, terj. Abdullah Ahmed al-Naim, Syracuse: Syracuse University Press.

60 Hassan Hanafi (1981), Dirasah al-Islamiyyah, Kaherah: Maktabah alMisriyyah.

61 Nasr Hamid Abu Zayd (1994), Mafhum al-Nass: Dirasah Fi Ulum alQuran, Beirut: Markaz al-Saqafi al-'Arabi.

62 Muhammad Arkoun (1994), Rethinking Islam: Common Question, Uncommon Answers, Boulder: Westview Press.

63 Muhammad Shahrur (1992), Al-Kitab wa al-Quran: Qira'ah Mua'sirah, Kaherah: Sina Li al-Nasyr.

64 Muhammad Abid al-Jabiri (1989), Takwin al-'Aql al-'Arabi, Beirut: Markaz Dirasah al-Widah al-'Arabiyyah.

65 Wael Hallaq (1997), A History of Islamic Legal Theory: An Introduction to Sunni Usul al-Fiqh, Cambridge: Cambridge University Press, hlm 245-253. 
Pendekatan Baru Maqasid al-Shariah Dalam Pengajian Syariah di Malaysia

mendapatkan pengetahuan, tren bayani ini akan mementingkan tiga perkara yang utama;

a) Redaksi lafaz teks dengan menggunakan kaedah bahasa Arab yang baku.

b) Menitikberatkan otoriti transmisi sesuatu teks nas agar ianya betul dan tidak terkeliru ataupun salah. Hal ini telah menyebabkan timbulnya ilmu riwayah Hadis.

c) Menitikberatkan penggunaan metode Qiyas. ${ }^{66}$

Apa yang jelasnya, walaupun pemikiran Islam amat memerlukan tren bayani ini, penggunaan pola bayani ini secara berlebihan akan menimbulkan permasalahan yang khusus seperti mana diulas oleh A. Khudri Soleh dengan katanya; "kerana hanya mendasarkan diri pada teks pemikiran bayani menjadi terbatas dan terfokus pada halhal yang bersifat aksidental bukan substansial, sehingga kurang bisa dinamis mengikuti perkembangan sejarah dan sosial masyarakat yang begitu cepat berubah. Kenyataannya, pemikiran Islam saat ini yang masih banyak didominasi pemikiran bayani fiqhiyyah kurang bias merespon dan mengimbangi perkembangan peradaban dunia." 67 Hal yang sama ditegaskan oleh Amir Mualim; "dominasi dan orientasi pemahaman bayani yang berlebihan akan menimbulkan persoalan dalam pemikiran hukum Islam. Kecenderungan kepada eksklusifisme dan truth-claim merupakan salah satu efek negatif yang selama ini dilakukan oleh sebahagian juris Muslim."68

(2) pendekatan Burhani yang mendasarkan diri kepada kekuatan rasio yang dilakukan melalui dalil-dalil logika. Hal ini dijelaskan oleh Amir Mualim dengan “ianya

66 A. Khudri Soleh (2004), Wacana Baru Filsafat Islam, Yogyakarta: Pustaka Pelajar, hlm 188-190.

67 Ibid., hlm 191.

68 Amir Mualim (2004), Ijtihad dan Legislasi Muslim Kontemporer, Yogyakarta: UII Press, hlm 109. 
Jurnal Fiqh: No. 3 (2006)

menjadikan realiti teks dan konteksnya sebagai sumber kajian. Dalam pendekatan burhani ini tercakup metode ta'lili yang berupaya memahami realitas teks berdasarkan rasionalitas; dan metode istilahi yang berusaha mendekati dan memahami realitas atau konteks berdasarkan filosofis. Realitas tersebut meliputi realitas alam, realitas sejarah, realitas sosial maupun realitas budaya. Tambahnya lagi; pemahaman terhadap reality social keagamaan dan sosial keislaman menjadi lebih memadai apabila dipergunakan pendekatan sosiologi, antropologi, kebudayaan dan sejarah. Dalam model pendekatan Burhani, keempat-empat metode ini berada dalam posisi yang saling berhubungan secara dialektis dan saling melengkapi membentuk jaringan keilmuan. ${ }^{69}$

(3) pendekatan Irfani yang biasanya digunakan oleh ahli tasawuf Islam. Ianya adalah pendekatan pemahaman yang bertumpu kepada pengalaman batiniyyah; zauq, qalb, wijdan, basirah dan intuisi. Kebenaran ilmiah yang diperolehi melalui pendekatan ini memang tidak boleh dinafikan sama sekali, namun begitu, penggunaannya secara berlebihan juga akan menimbulkan masalah kepada masyarakat awam yang mungkin tidak memahaminya secara mendalam.

Bagi sesetengah sarjana moden, untuk konteks zaman moden ini, para sarjana Islam, termasuklah pemikir hukum perlu mengetahui kekuatan dan kelemahan ketiga-tiga tren pemikiran ini dan perlu memadukannya secara integrasi bagi menghasilkan pemikiran yang mantap dirujuk kepada penggunaan kesemua aspek positif yang terkandung di dalam ketiga-tiga tren pemikiran tersebut. Apa yang tragisnya, sejarah Islam pernah menyaksikan pertentangan yang wujud di antara kalangan fuqaha, teologian dan sufi akibat daripada perbezaan kerangka pemikiran yang

$69 \quad$ Ibid., hlm 111. 
digunakan ini. ${ }^{70}$ Atas dasar ini, pengalaman sejarah pahit ini perlu dijauhkan agar ia tidak berulang lagi; yang boleh dilakukan melalui medium institusi pendidikan Islam. ${ }^{71}$

Contoh integrasi antara tren pemikiran bayani dan burhani dalam pemikiran hukum Islam boleh dilihat kepada gagasan yang cuba mengabungkan di antara ilmu usul al-fiqh dengan keilmuan moden lain yang sekaligus bakal melengkapkan lagi kaedah penyelidikan hukum Islam alternatif. Walaupun diakui ilmu usul al-fiqh ini memang hebat dan berteraskan world-view Islam sepenuhnya (tren bayani), ${ }^{72}$ tetapi untuk konteks zaman moden ini ia tidak boleh berdiri sendiri dan perlu disokong serta digabungkan dengan disiplin keilmuan lain. ${ }^{73}$

Manakala di peringkat mikro pula; APIUM telah cuba menerapkan beberapa pendekatan khusus membabitkan subjek Maqasid al-Shariah di dalam usaha memperkasakan pengajaran dalam pengajian syariah. Ianya terdiri daripada;

Pertama, pihak APIUM telah beberapa kali melakukan proses semakan terhadap subjek dan paradigma pengajaran disiplin usul al-fiqh yang diamalkan oleh APIUM. ${ }^{74}$ Usaha ini secara langsung bakal memastikan

70 Untuk melihat contoh pertentangan yang diakibatkan oleh ketiga tren pemikiran ini, Sila lihat Abdul Hadi W.M. (2001), Tasawuf Yang Tertindas: Kajian Hermeneutic Terhadap Karya-karya Hamzah Fansuri, Jakarta: Penerbit Paramadina.

71 Mahmud Arif (2002), "Pertautan Epistemologi Bayani dan Pendidikan Islam Masa Keemasan," Dalam al-Jamiah, V. 40, No. 1, hlm 126-154.

72 Hamid Fahmy Zarkasyi (2004), Tantangan Sekularisasi dan Liberalisasi di Dunia Islam, Surabaya: Penerbit Khairul Bayan.

73 Amir Mualim, Ijtihad dan Legislasi Muslim Kontemporer, hlm 112-115.

74 Sebagai contoh, Jabatan Fiqh dan Usul, APIUM telah mengadakan bengkel khusus yang cuba menerangkan tentang peri pentingnya proses semakan dibuat terhadap kaedah pengajaran Ilmu Usul alFiqh, pada 16hb. Jun 2005, bertempat di Balai Ilmu, APIUM. Bengkel ini telah dihadiri oleh seramai 35 orang wakil daripada IPTA/IPTS aliran Islam. 
Jurnal Fiqh: No. 3 (2006)

agar paradigma pengajian syariah semasa dapat memenuhi tuntutan globalisasi dan bukannya dijadikan sekadar bahan kajian sejarah hukum Islam yang mati dan kaku semata-mata. ${ }^{75}$ Dalam kurikulum pengajian keilmuan Islam subjek fiqh Islam seolah-olah telah dianggap sebagai pelajaran sejarah perundangan Islam semata-mata yang bukan lagi mampu menanggani situasi semasa. ${ }^{76}$ Fiqh sudah begitu lama dibiarkan beku dan statik, dan ini telah menyebabkan banyak persoalan hidup masyarakat tidak menepati kehendak syara' yang sebenar. ${ }^{77}$

Langkah ini juga telah disusuli dengan pelbagai kajian proaktif bagi memperkemaskan lagi maklumat semasa tentang keperluan dan kehendak agensi luar untuk graduan APIUM. ${ }^{78}$ Dengan berjayanya Universiti Malaya mendapat pensijilan MS ISO 9001: 2000 secara keseluruhan pada tahun 2003, hal ini sedikit sebanyak telah memberi impak yang besar kepada usaha meningkatkan nama baik universiti pada kaca mata masyarakat luar.

Kedua, memperkenalkan subjek perundangan Islam yang menekankan prinsip Maqasid al-Shariah dalam

75 Taha Jabir al-Alwani, "Taqlid and the Stagnation of the Muslim Mind," dalam The American Journal of Social Sciences, V. 8, No. 3, 1991, hlm 513.

76 Untuk melihat pendekatan dan kesan daripada amalan taqlid di Malaysia, lihat Rahimin Affandi Abdul Rahim (1995), "Budaya Taqlid di Dalam Masyarakat Melayu: Satu Tinjauan Ringkas," dalam Jurnal Syariah, V. 3, Bil. 1, hlm 30-32.

77 Muhammad Nabil Muhammad Syukri (2000), “Pembaharuan Fiqh: Keperluan dan Metodologi," dalam Pengasoh, Bil. 562, hlm 57.

78 Maklumat lanjut boleh didapati dalam Nor Aini Ali, Azizi Che Seman dan Mohd. Yahya Mohd Hussin, “Kajian Guna Tenaga Sarjana Muda Syariah dan Usuluddin (1996-2002)" - Vote F F0378/ 2003B, APIUM. Hal ini juga telah diusahakan sebagai contohnya oleh sekumpulan penyelidik daripada USM. Sila lihat Muhammad Syukri Salleh (2002), "Prospek Kerjaya Graduan Pengurusan Islam di Malaysia," dalam Wan Ab. Rahman Khudri Bin Wan Abdullah, Pengurusan Islam: Konsep dan Amalannya di Malaysia, Sintok: Penerbit UUM, hlm 53-76. 
pelbagai nama yang lebih menjuruskan kepada realiti Malaysia semasa dan bukannya bertumpu kepada realiti bukan Malaysia (Timur Tengah) daripada zaman pertengahan silam. Dalam soal ini, APIUM telah berusaha;

1. Memperkenalkan subjek Fiqh Malaysia (Fiqh Kontemporari), Pengantar Syariah dan Hukum Islam dan masyarakat di dalam kurikulum pengajian Syariah di peringkat ijazah pertama dan pasca siswazah. ${ }^{79}$ Gagasan Fiqh Malaysia tempatan ini adalah bagi menyediakan jawapan penyelesaian Islam untuk permasalahan yang dihadapi oleh masyarakat Malaysia semasa dan bukannya bergantung kepada warisan Fiqh silam yang tidak bersesuaian dengan realiti masyarakat Malaysia semasa. ${ }^{80}$

2. Berusaha membentuk intellectual discourse dengan menjadikan konsep Fiqh Malaysia sebagai asas utama untuk menyelesaikan permasalahan ummah Islam di Malaysia, yang dipecahkan kepada beberapa tema yang utama, seperti keperluan hukum Islam semasa, ${ }^{81}$ budaya $^{82}$ dan soal kepenggunaan. Intellectual discourse ini yang dibuat dalam bentuk seminar yang khusus bertujuan menyedarkan masyarakat dan bakal menjana perkembangannya

79 Maklumat lanjut boleh didapati dalam Buku Panduan Program Ijazah Dasar Tahun Akademik 1999/2000.

80 Lihat Rahimin Affandi Abd. Rahim (2003), “Konsep Fiqh Malaysia untuk Tamadun Alam Melayu Alaf Baru: Suatu Analisa Tentang Kepentingannya," dalam Jurnal Pengajian Melayu, bil. 10, 2003.

81 Seminar yang bertemakan "Hukum Islam Semasa Bagi Masyarakat Malaysia Yang Membangun" telah dianjurkan oleh APIUM pada 2627hb. Jun 1997, yang kemudiannya menghasilkan koleksi kertas kerja yang dibukukan dengan tajuk Hukum Islam Semasa Bagi Masyarakat Malaysia Yang Membangun.

82 Seminar yang menekankan tema ini telah dianjurkan oleh APIUM pada 23-24hb. Jun 1999, yang menghasilkan koleksi kertas kerja bertajuk Figh Malaysia: Ke Arah Pembinaan Figh Tempatan Yang Terkini. 
Jurnal Fiqh: No. 3 (2006)

dengan menerimapakai pandangan sarjana yang berbeza, untuk tujuan memantapkan lagi gagasan yang dipilih. Konsep Fiqh Malaysia ini bukanlah suatu konsep yang longgar, tetapi masih menggunakan pelbagai prinsip usul al-fiqh yang baku seperti prinsip talfiq, siyasah syariah, ijtihad tarjih dan maqasid al-shariah itu sendiri yang cuba diaplikasikan dengan mengambilkira realiti Malaysia semasa. ${ }^{83}$

3. Memperkenalkan subjek yang menunjukkan perkaitan antara Islam dengan persoalan dan disiplin moden; merangkumi subjek ekonomi, pengurusan, perundangan, pentadbiran awam dan sebagainya. Subjek-subjek ini dapat membiasakan pelajar dengan subjek keilmuan moden yang biasa dipakai dalam realiti kehidupan semasa. ${ }^{84}$

Ketiga, memperkenalkan subjek yang boleh menjanakan daya kritikal dan kebolehan menyelesaikan masalah semasa kepada pelajar. Berasaskan kepada laporan kelemahan pelajar IPTA semasa amnya dan IPTA Islam khususnya, yang dikatakan mempunyai kelemahan berfikir dan berkomunikasi yang betul, ${ }^{85}$ yang kemudiannya lulusan IPTA ini gagal memenuhi pasaran sasaran pekerjaan, maka pihak Universiti Malaya telah mengambil inisiatif dengan memperkenalkan dua subjek utama; kursus kemahiran berfikir dan berkomunikasi dan

83 Rahimin Affandi Abdul Rahim (2000), “Fiqh Malaysia: Suatu Tinjauan Sejarah," dalam Paizah Ismail (ed.), Fiqh Malaysia: Ke Arah Pembinaan Figh Tempatan Yang Terkini, Kuala Lumpur: APIUM, hlm 40-41.

84 Lihat Idris Awang (1995), "Perkembangan Pengajian di Fakulti Syariah Akademi Islam Universiti Malaya," dalam Jurnal Syariah, V. 3, Bil. 2, 1995, hlm 301-307.

85 Untuk maklumat lanjut sila lihat Mohamad Mohsin Mohamad (2000), "Kemahiran Berfikir di Alaf Baru," dalam Abdul Latif Samian dan Mohamad Sabri Haron (eds.), Pengajian Umum di Alaf Baru, Bangi: Penerbit UKM, hlm 195-204. 
Pendekatan Baru Maqasid al-Shariah Dalam Pengajian Syariah di Malaysia

kursus PBL (Problem Based Learning). Dalam komponen kedua-dua subjek ini, pelajar dilatih secara khusus tentang semua aspek kemahiran berfikir secara kritikal dan kemahiran sosial yang lain. Begitu juga halnya dengan subjek PBL yang biasanya dipakai untuk pelajar bidang perubatan, yang kononnya mampu melatih para pelajar menjadi pekerja yang boleh menganalisa setiap masalah yang timbul di dalam bidang masing-masing serta menyertakan jalan penyelesaian masalah terbaik untuk masalah tersebut. ${ }^{86}$

Merujuk khusus kepada pendekatan PBL yang membabitkan subjek hukum Islam, beberapa kaedah telah dijalankan;

1. Pelajar akan didedahkan dengan kerangka konsep dan senarai buku rujukan yang berotoriti untuk sesuatu subjek khusus seperti subjek Maqasid alShariah.

2. Pendedahan tentang senario sesuatu masalah hukum Islam sebenar akan dibentangkan untuk diselesaikan secara berkumpulan oleh pelajar, contohnya seperti membabitkan sesuatu fatwa yang dikeluarkan oleh Jawatankuasa Fatwa kebangsaan.

3. Pelajar perlu melakukan penyelidikan secara holistic terhadap sesuatu masalah yang diberikan, yang barang pastinya akan membabitkan pelbagai disiplin ilmu moden yang lain. Dalam soal ini, pelajar terpaksa melihat latarbelakang realiti sebenar sesuatu masalah itu timbul dan juga perlu menganalisis secara kritikal kandungan fatwa yang dikeluarkan oleh JFK, sama ada ianya bersesuaian dengan prinsip Maqasid al-Shariah dan realiti Malaysia.

86 Lihat sebagai contohnya Rahimin Affandi Abdul Rahim (2002),

"Memperkasakan Budaya Berfikir Islam: Satu Analisa," dalam Jurnal Afkar, Bil. 3, hlm 57-80. 
Jurnal Fiqh: No. 3 (2006)

4. Hasil penyelidikan pelajar ini akan dibentangkan di dalam kelas yang bakal dinilai oleh pelajar lain dan pensyarah itu sendiri.

Kaedah PBL ini menuntut kedua belah pihak iaitu pensyarah dan pelajar perlu berinteraksi dalam kontek yang lebih terbuka dan kritikal. Dalam soal ini, pendekatan pengajaran yang berbentuk banking concept dan teacheroriented perlu dijauhkan. Dalam pendekatan banking concept yang biasanya digunakan dalam paradigma Taqlid, ianya menafikan kreativiti seseorang pelajar dalam mengupas sesuatu persoalan. Manakala paradigma teacher-oriented pula merujuk kepada pendekatan yang terlalu bergantung sepenuhnya kepada pensyarah sehingga melupakan peranan yang perlu dimainkan oleh seseorang pelajar. Lebih tepat lagi, pelajar perlu bertindak dengan lebih proaktif di dalam kajiannya dan menganggap pensyarahnya hanya sebagai pembimbing dan fasilitator semata-mata. ${ }^{87}$

Dalam sejarah pendidikan perundangan Islam, ternyata Kaedah PBL ini walaupun diberikan dengan nama yang berbeza, sebenarnya pernah dijadikan metode utama di dalam pengajian syariah yang awal. Hal ini boleh dilihat dengan kaedah Mantik, Jadali, Istiqra'i dan tarjih dalam tradisi pengajian syariah silam. ${ }^{88}$ Apa yang lebih penting lagi, kaedah PBL ini bertepatan juga dengan model pendekatan filosofis yang memiliki sifat keilmuan, insklusif dan terbuka. Kelebihan pendekatan ini untuk bidang pengajian syariah boleh dirujuk kepada tiga perkara yang utama;

87 Maklumat lanjut boleh didapati dalam Abuddin Nata (2004), Sejarah Pendidikan Islam: Pada Periode Klasik dan Pertengahan, Jakarta: Rajawali Press, hlm 20-22.

88 Maklumat lanjut boleh didapati dalam Amir Mu'allim dan Yusdani (1999), Konfigurasi Pemikiran Hukum Islam, Yogyakarta, hlm 31-33 dan 64-67 
Pendekatan Baru Maqasid al-Shariah Dalam Pengajian Syariah di Malaysia

- Pencarian dan perumusan idea atau gagasan yang bersifat mendasar (fundamental ideas) dalam berbagai persoalan.

- Pengenalan dan pendalaman persoalan serta isu-isu fundamental dapat membentuk cara berfikir yang bersifat kritis.

- Proses ini bakal membentuk mentaliti dan kaedah berfikir yang mengutamakan kebebasan intelektual, sekaligus mempunyai sifat tolenran terhadap pelbagai pandangan dan kepercayaan yang berbeza serta bebas daripada fanatisme. ${ }^{89}$

Dalam konteks dunia moden, pendekatan filosofis ini yang dipakai sepenuhnya di dalam sistem pengajian keilmuan Islam di Barat telah mencetuskan pelbagai dinamisme yang berkaitan dengan perkembangan metodologi terkini dan dapatan kajian yang lebih bersifat terbuka. ${ }^{90}$ Rasanya, tidak salah kiranya penganut Islam cuba meniru secara selektif tentang apa yang dijalankan oleh dunia orientalism Barat. ${ }^{91}$

Namun begitu, perlu diingat bahawa pihak APIUM memang mengamalkan pendekatan selektif terhadap pedagogi pengajaran baru seperti mana dituntut oleh agenda globalisasi. ${ }^{92}$ Dengan matlamat untuk memajukan

89 Kamaruzzaman Bustaman Ahmad (2002), Islam Historis; Dinamika Studi Islam di Indonesia, Yogyakarta: Galang Press, hlm 9-10.

90 Untuk maklumat lanjut sila lihat Rahimin Affandi Abdul Rahim (2000), "Orientalisme dan Keutuhan Ummah Islam: Suatu Analisis," dalam Jurnal Syariah, V. 9, bil. 1, hlm 39-41.

91 Maklumat lanjut boleh dilihat dalam Ratno Lukito (1997), "Studi Hukum Islam Antara IAIN Dan McGill," dalam Yudian W. Asmin (ed.), Pengalaman Belajar Islam di Kanada, Yogyakarta: Titian Ilahi Press, hlm 152-162.

92 Lihat Rahimin Affandi Abdul Rahim (2004), "Menangani Cabaran Globalisasi: Satu Analisis Terhadap Pemikiran Reformis Semasa," dalam Mohd Fauzi Hamat, Mohd Fakhruddin Abd. Mukti dan Che Zarrina Sa'ari (eds.), Pemikiran Islam dan Cabaran Semasa, Kuala Lumpur: Jabatan Akidah dan Pemikiran Islam, APIUM, hlm. 213-238. 
Jurnal Fiqh: No. 3 (2006)

masyarakat menghadapi cabaran pemodenan, pelbagai IPTA/IPTS di Barat dan Malaysia sendiri telah ditubuhkan - dikatakan telah bertindak sebagai kilang untuk melahirkan tenaga mahir yang diperlukan oleh sektor pekerjaan. ${ }^{93}$ Kebanyakan IPTA/IPTS yang terpengaruh dengan tren pendidikan ala economisme ini telah memberikan penekanan utama kepada kemahiran teknikal semata-mata tanpa disertakan dengan pengetahuan akhlak dan moral yang mencukupi. ${ }^{94}$ Akibatnya, fenomena ini telah berjaya melahirkan golongan tenaga kerja yang mahir tetapi tidak beramanah dan tidak mempunyai wawasan keimanan yang jitu. ${ }^{95}$ Dengan penerapan falsafah pendidikan Islam (bagi melahirkan insan yang sempurna dan seimbang, dari segi jasad, ruh dan akal bagi memenuhi tujuan pengabdiaan kepada Allah), kita sekurangkurangnya mampu melahirkan tenaga kerja yang baik yang turut disertakan juga dengan daya ketahanan iman yang kukuh menghadapi cabaran hidup - boleh menjadi pengubat jiwa yang berteraskan kepada harapan keakhiratan seandainya dilanda dengan sesuatu masalah. ${ }^{96}$

Keempat, menekankan kepentingan mengguna, menghidupkan dan memberi nafas baru kepada prinsipprinsip syariah seperti Maqasid al-Shariah yang boleh dijadikan sebagai asas kepada program pembangunan Islam di Malaysia. Ianya juga boleh dibuat dalam bentuk kajian ilmiah terhadap realiti praktis sesuatu institusi yang

93 Lihat Noraini Othman (2000), "Globalisasi, Pendidikan dan Modeniti di Malaysia," dalam Abdul Rahman Embong (ed.), Malaysia Menanggani Globalisasi: Peserta atau Mangsa, Bangi: UKM, hlm 153

94 Wan Mohd Nor Wan Daud (1998), The Educational Philosophy and Practice of Syed Muhammad Naquib al-Attas: An Exposition of the Original Concept of Islamization, Kuala Lumpur: ISTAC, hlm 230.

95 Zaini Ujang (1993), Universiti: Mendukung Tradisi Intelektual, Kuala Lumpur: Institut Kajian Dasar, hlm 28-29.

96 Nurcholish Madjid (2003), Islam Agama Kemanusiaan: Membangun Tradisi dan Visi Baru Islam Indonesia, Jakarta: Penerbit Paramadina, hlm 215-222. 
Pendekatan Baru Maqasid al-Shariah Dalam Pengajian Syariah di Malaysia

disertakan pula dengan alternatif pilihan. ${ }^{97}$ Antara beberapa contoh yang relevan;

1. Tindakan Prof. Ahmad Ibrahim yang menggalakkan pelajar lepasan ijazah mengkaji kelemahan English Common Law (ECL) yang dipakai di Malaysia, yang secara pastinya bakal disertakan dengan pelbagai alternatif baru menggantikan pemakaian ECL ini dengan mewujudkan Malaysia Common Law sendiri, yang berteraskan pelbagai prinsip-prinsip hukum Islam seperti konsep Urf, Maqasid al-Shariah, Maslaha, Siyasah Syariah dan lainnya. ${ }^{98}$

2. Tindakan APIUM yang menggalakkan para pelajar pasca siswazah menjadikan prinsip Maqasid al-Shariah sebagai asas ataupun landasan teori bagi sesuatu isu penting yang timbul di dalam masyarakat semasa. Antara isu-isu ini yang termasuk dalam subjek fiqh kepenggunaan adalah soal gender, ${ }^{99}$ rawatan kumbahan air, ${ }^{100}$ sains

97 Norhashimah Mohd Yasin (1994), "Islamisation or Malaynisation: A Study on the Role of Islamic Law in the Economic Development of Malaysia: 1969-1993," tesis Ph.D untuk School of Law, University of Warwick, England; Ahmad Hidayat Buang (1997), “Muamalat di Malaysia: Suatu Tajdid atau Reaksi Pasaran," dalam Dinamisme Pengajian Syariah, Kuala Lumpur: Berita Publishing Sdn Bhd, hlm 107124; Rahimin Affandi Abdul Rahim (1999), "Islamic Legal Reform in the Administration of Islamic Law in Malaysia: A Critical Analysis," tesis Ph.D untuk University of Birmingham.

98 Lihat sebagai contohnya Anuar Ramli (2002), “Asas Hukum Dalam Budaya: Kajian Terhadap Beberapa Aspek Hubungan Sosial Dalam Kebudayaan Malaysia," tesis Sarjana untuk Jabatan Fiqh dan Usul, APIUM, dan Mohd Fauzi Bin Audzir (2002), “Uruf Tempatan di Negeri Kedah dan Kesannya Terhadap Perubahan Hukum: Satu Analisis," tesis Sarjana untuk Jabatan Fiqh dan Usul, APIUM.

99 Aba Yazid (2003), "Implementasi Teori Maqasid al-Syariah Terhadap Konsep Nikah, Wilayah Nikah dan Hak-hak Perempuan di Dalamnya," tesis Sarjana untuk Jabatan Fiqh dan Usul, APIUM.

100 Nadzirah Ismail (2004), "Status Kesucian Air Kumbahan Yang Dirawat Melalui Kaedah Rawatan Oleh Indah Water Konsortium," tesis Sarjana untuk Jabatan Fiqh dan Usul, APIUM. 
Jurnal Fiqh: No. 3 (2006)

perubatan, ${ }^{101}$ bio-perubatan, ${ }^{102}$ farmasi, ${ }^{103}$ astronomi, ${ }^{104}$ hasil tenusu $\mathrm{F} \& \mathrm{~N},{ }^{105}$ isu perubahan sosial, ${ }^{106}$ Fatwa $\mathrm{JFK}^{107}$ dan banyak lagi.

Kelima, membangunkan kaedah penyelidikan hukum Islam yang bersifat semasa ataupun memperkemaskan lagi struktur dan fungsi dinamisme hukum Islam, khususnya yang membabitkan prinsip Maqasid al-Shariah. Dalam soal ini beberapa usaha telah dilakukan, seperti;

1. Menekankan tentang kepentingan penyelidikan ilmiah di dalam proses pembangunan pemikiran. ${ }^{108}$ Hal ini boleh dibuat dengan menanamkan ke dalam diri seseorang sarjana Islam tentang kepentingan penyelidikan ilmiah

101 Azhar Abdul Aziz (2002), "Peranan Sains Perubatan Dalam Menentukan Hukum Keharusan Fasakh Kerana Penyakit," tesis Sarjana untuk Jabatan Fiqh dan Usul, APIUM.

102 Nizaita Omar (1999), “Beberapa Kaedah Perubatan Moden Menurut Perspektif Islam," tesis Sarjana untuk Jabatan Fiqh Dan Usul, APIUM.

103 Mohd Sharkawi Shaadan (2003), "Penggunaan Bahan Haram Dalam Perubatan: Kajian di Pusat Perubatan Universiti Malaya, Kuala Lumpur," tesis Sarjana untuk Jabatan Fiqh dan Usul, APIUM.

104 Mohamad Amin Abu Bakar (2002), "Pemakaian Asas Astronomi Dalam Menentukan Arah Qiblat di Malaysia: Satu Pendekatan Hukum," tesis Sarjana untuk Jabatan Fiqh dan Usul, APIUM.

105 Noor Asiah Binti Aling (2004), "Barangan Tenusu Keluarga F\&N: Satu Kajian Berasaskan Hukum Kepenggunaan Islam," tesis Sarjana untuk Jabatan Fiqh dan Usul, APIUM.

106 Muhammad Firdaus Nurul Huda (2002), Kesan Perubahan Sosial Terhadap Hukum Islam: Satu Kajian Tentang Metodologi Syariah dan Pelaksanaannya, Kuala Lumpur: Thinker's Library.

107 Mohd Nazri Bin Asiabu (2003), "Penggunaan Maslahah Dalam Fatwa: Kajian Kes Bagi Fatwa-fatwa Yang Dikeluarkan oleh Majlis Agama Fatwa Kebangsaan," tesis Sarjana untuk Jabatan Fiqh dan Usul, APIUM.

108 Lihat sebagai contohnya Rahimin Affandi Abd. Rahim, "Pembangunan Hukum Islam Di Malaysia: Satu Analisa," dalam kertas kerja Seminar Pembangunan Ummah 2002 Pulau Pinang, Sempena Hari Jadi Tuan Yang Terutama Negeri Pulau Pinang, anjuran Jabatan Mufti Pulau Pinang, pada 11hb. Julai 2002. 
dalam usaha mengangkat martabat ummah. ${ }^{109}$ Apa yang menyedihkan adalah kedapatan sesetengah orang yang beranggapan bahawa sesuatu perjuangan Islam hanya perlu dilakukan dalam kegiatan politik semata-mata dan memandang rendah terhadap kegiatan keilmuan yang membabitkan penyelidikan ilmiah. Sikap simplistik ini menjadikan seseorang Islam itu lebih banyak bercakap dalam soal perjuangan tanpa mengisi matlamat perjuangannya dengan pengisian keilmuan yang bermakna. ${ }^{110}$

2. Memperincikan kaedah mencari maklumat terperinci terhadap objek masalah, persoalan mukallaf yang menjadi fokus utama di dalam sesuatu permasalahan hukum. Dalam soal ini, selain dari kaedah usul al-fiqh, seseorang fuqaha perlu menerima pakai ataupun bersikap positif yang bersesuaian dengan pendekatan ijtihad jama'i terhadap beberapa kaedah sains sosial moden, di dalam usaha pencarian maklumat terhadap punca masalah hukum. ${ }^{111}$ Sebagai contohnya, kita boleh memberikan beberapa perkaitan antara prinsip hukum Islam dengan bantuan sains sosial moden, seperti;

a) Penggunaan adat tempatan ('urf) Melayu sebagai asas penetapan dan sumber hukum tambahan terhadap sesuatu permasalahan hukum yang timbul di dalam masyarakat. ${ }^{112}$ Apa yang jelasnya, sebelum sesuatu adat kebiasaan Melayu itu boleh diterima

109 Maklumat lanjut tentang soal ini boleh didapati dalam Rahimin Affandi Abd. Rahim (2000), "Etika Penyelidikan Islam: Satu Analisa," dalam Jurnal Afkar, Bil. 1, hlm 179-182.

110 Mahmood Zuhdi Abdul Majid (1997), Pengantar Undang-undang Islam di Malaysia, Kuala Lumpur: Penerbit UM, hlm 7-11.

111 Lihat Rahimin Affandi Abd. Rahim (2002), “Ke Arah Penyediaan Kaedah Penyelidikan Hukum Islam Yang Terkini: Satu Pengenalan," dalam Jurnal Syariah, V. 10:1, hlm 1-24.

112 Md. Salleh Haji Ahmad, “Pengajian Syariah: Hubungannya Dengan Adat Resam Serta Keadaan Tempatan," dalam Dinamisme Pengajian Syariah, hlm 63-66. 
Jurnal Fiqh: No. 3 (2006)

pakai penggunaannya untuk tujuan penetapan hukum baru, fuqaha dengan bantuan pengajian kebudayaan Melayu perlu memastikan sama ada adat yang menjadi amalan kebiasaan masyarakat Melayu tersebut tergolong di dalam adat yang sahih ataupun fasid. ${ }^{113}$

b) Penggunaan konsep Siyasah syariah yang memberi kuasa terhad kepada sesuatu kuasa pemerintah Islam untuk menguatkuasakan sesuatu dasar baru yang bersesuaian dengan maslaha kepentingan masyarakat Islam. ${ }^{114}$ Demi untuk mengelakkan penggunaan konsep ini yang kerap digambarkan sebagai alat utama untuk sesuatu dasar yang menindas, ${ }^{115}$ seseorang fuqaha itu perlu meneliti banyak perkara, seperti bentuk kepentingan (maslaha) yang cuba hendak ditekankan berasaskan realiti keutamaan yang sangat diperlukan oleh sesuatu masyarakat, ${ }^{116}$ beberapa Qawaid fiqhiyyah yang mengabungkan antara kaedah mengutamakan keredaan Allah dan makhluk ${ }^{117}$ dan juga realiti dasar politik dan sosial yang diamalkan oleh

113 Rahimin Affandi Abdul Rahim (2003) “Pengajian Sosial dan Hubungannya Dengan Pembinaan Hukum Islam Semasa: Satu Analisa" dalam Rahminah Muharam (ed.), Isu-Isu Sains Sosial Dari Perspektif Islam, Kota Kinabalu: Universiti Malaysia Sabah, hlm 1-34.

114 Maklumat lanjut boleh didapati dalam Shukeri Mohamed, "Siasah Syar'iyyah dan Kedudukannya Sebagai Metod Penentuan Hukum," dalam Abdul Karim Ali (ed.) Hukum Islam Semasa Bagi Masyarakat Malaysia, hlm 99-124.

115 Lihat Rahimin Affandi Abdul Rahim (2003), "Pengamalan Ilmu Usul al-Fiqh di Dalam Sastera Undang-undang Melayu: Satu Analisa," dalam Muhammad Mokhtar Hassan (ed.), Kesusasteraan dan UndangUndang, Kuala Lumppur: Akademi Pengajian Melayu, Universiti Malaya, hlm 158-179.

116 Lihat sebagai contohnya perbincangan yang dibuat oleh Sukeri Mohamad (1996), "Maqasid al-Syariah Dalam Pengurusan Harta," dalam Monograf Syariah, V. 4, hlm 1-25.

117 Lihat sebagai contohnya Mohd Salleh Haji Ahmad (1999), Pengantar Syariah, Kuala Lumpur, hlm. 210-243. 
Pendekatan Baru Maqasid al-Shariah Dalam Pengajian Syariah di Malaysia

sesebuah kerajaan yang memerintah, ${ }^{118}$ yang boleh diperolehi daripada disiplin politik dan sosiologi.

c) Penggunaan konsep Rukhsah dan Darurat yang memberikan kelonggaran di dalam sesuatu amalan taklif syarak untuk seseorang penganut Islam. Dalam soal ini fuqaha perlu meneliti bentuk dan halangan sosial dan ekonomi yang terpaksa ditanggung oleh penganut Islam yang secara jelas terkandung di dalam disiplin ekonomi dan sosiologi. ${ }^{119}$

3. APIUM mendokong penuh pandangan yang menetapkan bagaimana sebarang prinsip hukum Islam seperti prinsip Maqasid al-Shariah ini perlu terbuka dengan perkembangan S\&T moden. ${ }^{120}$ Perkembangan sains dan teknologi moden ini telah membekalkan fuqaha dengan banyak maklumat dan hakikat kejadian yang terkini. Apa yang agak kabur dari segi hakikatnya suatu masa dahulu, dengan perkembangan sains dan teknologi terkini, hakikat ini menjadi semakin jelas dan terang. ${ }^{121}$ Banyak nas-nas Quran dan sunnah yang suatu masa dahulu terpaksa diterima secara ta'budiyyah semata-mata ${ }^{122}$ kerana fuqaha

118 Lihat sebagai contohnya kupasan Husin Mutalib (1994), "Islamization in Malaysia: Between Ideals and Realities," dalam Islam, Muslims and The Modern State; Case-Studies of Muslims in Thirteen Countries, London, hlm. 166-167.

119 Lihat sebagai contohnya kupasan yang diberikan oleh Muhammad Firdaus (1999), "Kesan Perubahan Sosial Terhadap Hukum Islam," tesis Ph.D untuk Jabatan Fiqh dan Usul, APIUM, hlm 94-100.

120 Maklumat lanjut boleh didapati dalam Rahimin Affandi Abdul Rahim, "Sains dan Teknologi (S\&T) Serta Pengajian Syariah di Malaysia: Analisa Terhadap Pengalaman APIUM," dalam Prosiding Seminar Kebangsaan Fiqh Semasa 2003: Menghadapi Cabaran Globalisasi, tarikh 24-25 September 2003, anjuran bersama Jabatan Syariah, Fakulti Pengajian Islam, UKM dan Kolej Islam Selangor Darul Ehsan, Bangi, Selangor, hlm 568-581.

121 Anuar Zaini, “Kemajuan Sains dan Teknologi dan Kesannya Terhadap Perkembangan Hukum Islam Masa Kini," dalam Hukum Islam Semasa, hlm 132-144.

122 Harun Nasution (1989), Islam Rasional: Gagasan dan Pemikiran, Jakarta, hlm 116-118. 
Jurnal Fiqh: No. 3 (2006)

tidak mampu mengkajinya secara mendalam telah mula berubah dengan perkembangan sains ini, yang antara lainnya kebenaran nas-nas Quran lebih-lebih lagi dalam soal hakikat sesuatu perkara telah dibuktikan sebagai benar dan dapat dijadikan sebagai bukti tentang kebesaran kuasa Allah ke atas makhluk. ${ }^{123}$

Untuk itu, sesuai dengan prinsip keanjalan syariah yang berasaskan dan menekankan pembuktian yang lebih betul dalam penetapan hukum, ${ }^{124}$ fuqaha zaman moden ini perlu menilai kembali mana-mana pendapat silam yang bertentangan dengan penemuaan sains moden. Sikap yang mahu berkeras dengan pendapat yang lama (konservatif) tidak ada tempatnya dalam syariah Islam. ${ }^{125}$ Begitu juga fuqaha era moden ini telah merumuskan bagaimana seseorang fuqaha perlu mengambilkira pengunaan teori Siyaq (kontektual) di dalam menilai relevansi sesuatu nas syarak terhadap sesuatu persoalan baru yang timbul di dalam masyarakat. ${ }^{126}$ Terdapat beberapa contoh semasa yang dipegang oleh fuqaha moden untuk menjelaskan pendekatan ini, antaranya;

a) tindakan yang membenarkan proses bedah siasat (post-mortem) ke atas mayat untuk mengetahui sebab sebenar kematian si mati dan untuk tujuan pembelajaran-pendidikan perubatan. Perkembangan sains perubatan moden ini telah ditanggap dengan begitu positif oleh kebanyakan fuqaha moden yang kelihatannya telah mencabar ketetapan yang

123 Osman Bakar (1994), "Ilmu Tauhid Berasaskan Kajian Saintifik," dalam Ilmu dan Kecemerlangan Dari Perspektif Islam, Kuala Lumpur, hlm 1-10.

124 Shawkani (1974), Al-Qawl al-Mufid fi Adillah al-Ijtihad wa al-Taqlid, Kaherah, hlm 7.

125 Ibn Taimiyyah (1963), Majmu' Fatawa Shaikh al-Islam Ahmad Ibn Taimiyyah, Riyadh, V. 20, hlm 208-209.

126 Maklumat lanjut boleh didapati dalam Yunus Soualhi (1999), "The Doctrine of Certainty in the Islamic Legal Methods of Inference," tesis Ph.D untuk Jabatan Fiqh dan Usul, APIUM, hlm 90-154. 
Pendekatan Baru Maqasid al-Shariah Dalam Pengajian Syariah di Malaysia

diputuskan oleh fuqaha silam, tetapi lebih bersesuaian dengan prinsip kebenaran hakiki. ${ }^{127}$

b) pendapat yang diutarakan oleh Ali Mansur yang mencabar metode penetapan tradisi bagi permulaan bulan Ramadan yang berasaskan anak bulan tersebut dapat dilihat dan disahkan oleh dua orang saksi. ${ }^{128}$ Bagi beliau, sudah sampai masanya fuqaha Islam moden melakukan penetapan permulaan bulan Ramadan menggunakan sains Astronomi moden berasaskan peralatan yang canggih dan pengiraan matematik yang lebih tepat dan dapat disebarkan hasilnya ke seluruh dunia menggunakan sistem kominikasi moden. ${ }^{129}$

4. Mengalakkan kaedah penelitian hukum Islam (sosiologi Hukum Islam) yang dilaksanakan dalam masyarakat. Kaedah ini bertujuan memastikan keseimbangan di antara idealism yang terkandung dalam hukum Islam (law in book) dengan realiti perlaksanaannya di dalam masyarakat (law in action), yang menggunakan pendekatan kajian sosiologi hukum Islam. ${ }^{130}$ Memandangkan kaedah ini masih lagi terlalu baru, proses pembangunan kaedah ini perlu dibangunkan secara sentesis oleh sarjana hukum Islam moden berasaskan kepada disiplin sosiologi undang-undang Barat. Antara kandungan yang difikirkan perlu untuk kaedah sosiologi hukum Islam ini adalah; ${ }^{131}$

127 Maklumat lanjut boleh didapati dalam Vardit Rispler Chaim (1996), "Postmortem Examinations in Egypt," dalam Muhammad Khalid Mas'ud (ed.), Islamic Legal Interpretation: Muftis and Their Fatwas, London, hlm 278-285.

128 P.E. Walker (1978), “Eternal Cosmos and the Womb of History: Time in Early Ismaili Thought," dalam IJMES, V. ix, hlm 355.

129 Ali Mansur (1948), al-Majallah, hlm 840-842.

130 Agak banyak kajian di peringkat Ijazah Pertama dan Pasca Siswazah di APIUM yang menggunakan kaedah sosiologi hukum Islam ini.

131 Amir Mu'allim, Konfigurasi Hukum Islam, hlm 46-47. 
Jurnal Fiqh: No. 3 (2006)

a) Kajian keberkesanan hukum Islam yang telah dilaksanakan di dalam masyarakat, sama ada ianya mampu menyelesaikan masalah hukum ataupun sebaliknya.

b) Kajian tentang dampak hukum Islam yang terlaksana yang menumpukan perhatian terhadap kesan dari aplikasi hukum untuk jangka masa panjang dan pendek.

c) Kajian tentang struktur dan lembaga (organisasi) yang bertanggungjawab memutus dan menguatkuasakan hukum Islam di dalam masyarakat.

d) Kajian tentang teori-teori yang menjayakan dan mengagalkan pelaksanaan hukum Islam yang kedapatan di dalam sejarah perundangan Islam.

5. Menggalakkan perkaitan ataupun gabungan pembelajaran prinsip Maqasid al-Shariah dengan konsep Fiqh Awlawiyyah yang lebih menekankan kepada perkiraan realiti masyarakat Malaysia semasa. ${ }^{132}$ Gabungan ini antara lainnya perlu bersifat terbuka dan tidak membataskan penyelesaian kepada sesuatu mazhab semata-mata. Apa yang lebih penting lagi, seseorang fuqaha perlu mengakui dan menghormati pandangan fuqaha lain yang terbabit di dalam proses mendapatkan maklumat untuk sesuatu penyelidikan hukum dan seterusnya melakukan analisa yang terbaik terhadap fakta terbabit. Hal ini boleh dilakukan dengan pendekatan model fiqh perbandingan membabitkan semua mazhab terbesar di dalam Islam, dengan cara menerima pakai sumber yang berbeza, meneliti hujah yang digunakan secara terbuka dan memilih untuk menerima pakai mana-mana pendapat

132 Lihat sebagai contohnya Abdul Karim Ali (2000), "Faktor-Faktor Semasa dan Setempat di Malaysia Yang Boleh Mempengaruhi Penafsiran Nas Syarak Dalam Menentukan Hukum:, dalam Paizah Ismail (ed.) (2000), Fiqh Malaysia: Ke Arah Pembinaan Figh Tempatan Yang Terkini, Kuala Lumpur: APIUM, hlm 65-69. 
yang lebih bertepatan dengan kehendak syarak. ${ }^{133}$ Dalam pendekatan ini seseorang fuqaha perlu membebaskan diri dari belenggu fanatik mazhab dan mengutamakan maslaha perpaduan ummah melebihi segala-galanya.

Gabungan ini dilihat akan lebih menyerlahkan sifat kesyumulan yang dimiliki oleh hukum Islam, disamping ianya dapat mengelakkan prinsip Maqasid al-Shariah ini digunakan secara sewenang-wenangnya oleh kalangan yang tidak bertanggungjawab, dengan menggunakan topeng Maqasid al-Shariah. Hal ini boleh dikatakan sebagai fenomena yang agak mendesak demi untuk memastikan agar konsep dan prinsip hukum Islam yang terpilih tidak disalah gunakan bagi tujuan mendapatkan justification (pengesahan dan keabsahan) syarak terhadap mana-mana amalan yang bertentangan dengan prinsip asas Islam. ${ }^{134}$ Antara aspek keutamaan yang menjadi sandaran ini; ${ }^{135}$

a) Keutamaan kualiti daripada kuantiti.

b) Keutamaan ilmu daripada amal.

c) Keutamaan objektif daripada bentuk lahir.

d) Keutamaan ijtihad daripada Taqlid.

e) Keutamaan memudahkan daripada memayahkan.

f) Keutamaan kerja-kerja untuk faedah umum daripada kerja untuk faedah sendiri.

g) Keutamaan Fardu Ain daripada fardu kifayah.

h) Keutamaan hak masyarakat daripada hak individu.

133 Perbincangan lanjut boleh didapati dalam Paizah Hj. Ismail, “Fiqh al-Awlawiyat: Konsep dan Hubungannya Dengan Fiqh alMuwazanat, Fiqh al-Syar' dan Fiqh al-Waqi'" dalam Hukum Islam Semasa Bagi Masyarakat Malaysia Yang Membangun, hlm 73-80.

134 Mahmood Zuhdi Abdul Majid (1999), "Hukum Islam Semasa Bagi Masyarakat Malaysia Yang Membangun," dalam Hukum Islam Semasa Bagi Masyarakat Malaysia Yang Membangun, Kuala Lumpur, hlm 8-10.

135 Mahmood Zuhdi Ab Majid dan Paizah Ismail (2004), Pengantar Pengajian Syariah, Kuala Lumpur: al-Baian Corporation Sdn Bhd, hlm 203-207. 
Jurnal Fiqh: No. 3 (2006)

\section{KESIMPULAN}

Sebagai rumusan akhir, dapat kita simpulkan bahawa usaha untuk menghidupkan peranan hukum Islam di zaman moden ini menggunakan prinsip Maqasid alShariah bukanlah suatu usaha yang mudah. Ianya perlu dirancang secara berhemah di peringkat kerangka konseptual menggunakan sepenuhnya disiplin usul al-fiqh, serta di peringkat pelaksanaannya pula perlu diterapkan dengan pendekatan pedagogi baru di dalam pengajian syariah. Dengan menjadikan precedent fuqaha silam yang tidak jemu-jemu merancang pembangunan disiplin usul alfiqh agar ianya sesuai dengan tuntutan semasa, hal yang sama perlu dilakukan serta mendapat dokongan daripada kalangan fuqaha di Malaysia. Apa yang jelasnya, inisiatif yang cuba dilaksanakan oleh APIUM ini masih belum lagi sempurna dan perlu diteruskan secara berperancangan rapi oleh mana-mana IPTA Islam yang lain. 